\title{
Summaries of LLNL Geothermal Energy Program
}

\author{
P. Kasameyer
}

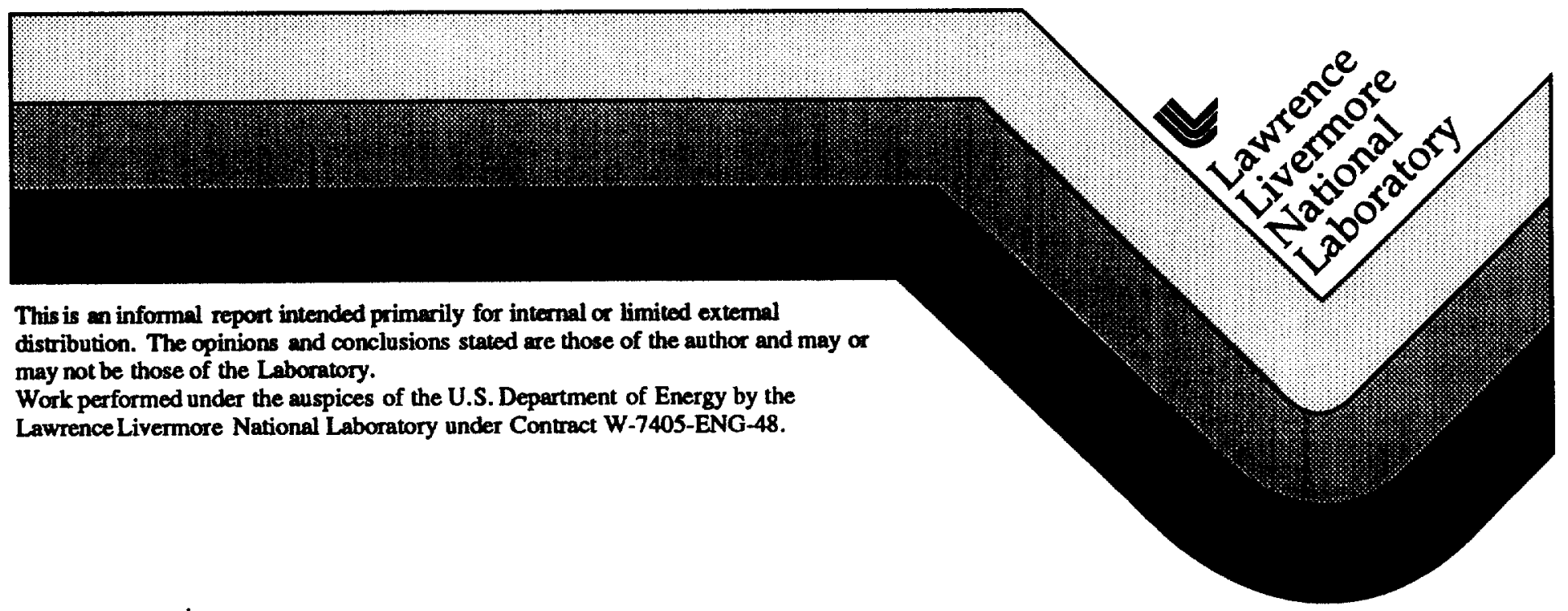




\section{DISCLAIMER}

This document was prepared as an account of work sponsored by an agency of the United States Government. Neither the United States Government nor the University of California nor any of their employees, makes any warranty, express or implied, or assumes any legal liability or responsibility for the accuracy, completeness, or usefulness of any information, apparatus, product, or process disclosed, or represents that its use would not infringe privately owned rights. Reference herein to any specific commercial product, process, or service by trade name, trademark, manufacturer, or otherwise, does not necessarily constitute or imply its endorsement, recommendation, or favoring by the United States Government or the University of California. The views and opinions of authors expressed herein do not necessarily state or reflect those of the United States Government or the University of California, and shall not be used for advertising or product endorsement purposes.

This report has been reproduced directly from the best available copy.

Available to DOE and DOE contractors from the Office of Scientific and Technical Information

P.O. Box 62, Oak Ridge, TN 37831

Prices available from (615) 576-8401, FTS 626-8401

Available to the public from the

National Technical Information Service

U.S. Department of Commerce

5285 Port Royal Rd.,

Springfield, VA 22161 


\section{LLNL Geothermal Energy Program \\ Progress Report, 1996}

The enclosed summaries describe the primary published results of the

Lawrence Livermore National Laboratory Geothermal Program in 1996. The LLNL Geothermal Program performs research for the United States

Department of Energy Geothermal Research Program and for the Idaho Office of the Department of Energy.

Our purpose is to carry out and document research that the US Geothermal Industry recognizes as reducing the cost or increasing the effectiveness of geothermal exploration or reservoir development. The ultimate goal of this research is to increase the use of geothermal energy, which ia a relatively inexpensive source of energy that produce very low $\mathrm{CO}_{2}$ emissions. We solve geophysical, petrophysical and geochemical problems related to reservoir identification, characterization and utilization. We carry out projects in cooperation with the members of the US Geothermal Industry, who provide us with samples, logistic and field support, and shared data needed to accomplish our studies.

Efforts during this year have included studies in several technical areas:

Integrated Geophysical studies of Geothermal Systems. We have participated with Trans-Pacific Geothermal in a study of the El HoyoMonte Galan geothermal prospect in Nicaragua. Our role in this project has been to participate in an international seismic effort to understand seismicity in this volcanic area. In addition, we participated in a review of geophysical and geological data from the Carson Sink Geothermal Area and a seismic velocity and attenuation model of the SE Geysers Field.

Use of mechanical and electrical properties to place constraints on fluid saturation and fracture locations in geothermal fields. This work was done in the LLNL Petrophysics Lab and at New England Research. We completed studies of electrical resistivity and X-ray imaging of core from The Geysers well SB-15D. In addition, we tested and calibrated a long-spacing EM logging tool, and performed calculations regarding the performance of Electrical Resistance Tomography for monitoring fluid injection.

Geochemical and isotopic studies of granite-hosted geothermal systems; and development of a well-logging database for geothermal systems. We have used Accelerator Mass Spectroscopy and Geochemical modeling to study water-rock interactions at Coso, Tiwi and Dixie Valley Geothermal Fields.

Power Plant Operations and Maintenance. We have initiated studies of the reduction of the costs of $\mathrm{H}_{2} \mathrm{~S}$ abatement at The Geysers, and are evaluating continuous infrared spectral monitoring to determine $\mathrm{H}_{2} \mathrm{~S}$ emissions from cooling towers.

This work has been funded by the Geothermal Research Program of the US Department of Energy. 
The following summaries can be found in this report:

Geochemical studies of geothermal systems - C.J. Bruton, G.J. Nimz

$X-R a y$ visualization of capillarity effects in preserved core from the Geysers - B.P. Bonner, J.J. Roberts and D.J. Schneberk

Fracture mapping in geothermal fields with long-offset induction logging M. Wilt, and P. Kasameyer

Reduction of operating and maintenance costs at geothermal power plants C.J. Bruton, J. Rard, and C. Stevens

Electrical properties of rocks at geothermal-reservoir conditions - A. Duba, J. Roberts, and B. Bonner

Interpretation of field seismic observations at the geysers geothermal field in the context of laboratory measurements - G.N. Boitnott

Lawrence Livermore National Laboratory's Geothermal publications 


\title{
Geochemical studies of geothermal systems
}

\author{
Carol J. Bruton, Gregory J. Nimz
}

\section{KEY WORDS}

geochemistry, ${ }^{36} \mathrm{Cl} / \mathrm{Cl}$, isotopes, geochemical simulations, Coso, Tiwi, scale

\section{PROJECT BACKGROUND AND STATUS}

This project commenced in the latter half of FY1996 to apply established LLNL expertise in geochemistry, especially geochemical simulations of fluid-rock interactions and isotopic measurements using accelerator mass spectrometry, to exploration and development issues in the geothermal industry.

\section{PROJECT OBJECTIVES}

Work is currently proceeding in three areas: a) using ${ }^{36} \mathrm{Cl} / \mathrm{Cl}$ isotopic compositions in the Coso geothermal field in California as a diagnostic tool for characterizing hydrologic systems; b) using computer simulations to evaluate the physical and chemical conditions controlling alteration mineralogy in the Tiwi geothermal field, Philippines; c) using geochemical analysis to determine causes of scale formation and chemical consequences of fluid mixing and injection in the Dixie Valley geothermal field, Nevada.

\section{Technical Objectives}

- Define the hydrologic system and host rock interactions at Coso over time using isotopic compositions, such as ${ }^{36} \mathrm{Cl} / \mathrm{Cl}$, as diagnostic tools.

- Constrain the physical and chemical evolution of the Tiwi geothermal field using geochemical modeling simulations of fluid-rock interactions.

- Identify causes of scaling problems, and evaluate potential for adverse reactions resulting from fluid mixing and injection at Dixie Valley. Develop potential solutions.

\section{Expected Outcomes}

- Characterize the hydrologic structure of geothermal systems, determine the ages and origins of geothermal waters, and differentiate among potential sources of solutes in geothermal waters through the use of isotopes.

- Better locate geothermal wells by: 1) assessing the importance of specific mineral associations as mineral geothermometers and permeability indicators; 2) predicting fluid compositions; and 3) understanding the 
chemical evolution of geothermal systems in volcanic terrains through the use of geochemical simulations.

- Determine causes of observed scale formation, and identify means of controlling scale formation. Evaluate potential for adverse fluid-fluid and fluid-rock interactions during surface mixing of fluids and subsequent injection into the reservoir.

\section{APPROACH}

Two approaches are being taken. First, we are applying relatively new techniques for accelerator mass spectrometry to measure isotopes such as ${ }^{36} \mathrm{Cl} / \mathrm{Cl}$ in geothermal systems. Accelerator mass spectrometry is used to accurately measure low abundance natural or anthropogenic isotopes on small samples. Acquired data are being used to better understand the hydrology of geothermal systems and the fluid-rock interactions that occur throughout the evolution of the system.

Second, we are applying geochemical computer simulations of fluid-rock interactions in order to better understand the relationships between fluid chemistry and mineral alteration in geothermal systems. Geochemical analysis is also being used to simulate the formation of precipitates during fluid mixing.

\section{RESEARCH RESULTS}

${ }^{36} \mathrm{Cl} / \mathrm{Cl}$ ratios have been measured in the Coso geothermal system. Results were used to evaluate the source and residence time of the chlorine, the timing of its input, and potential sources of the thermal water.

The source of the reservoir fluids in the Tiwi geothermal field and the chemical and physical processes responsible for producing observed vein parageneses were evaluated using the React geochemical modeling code (Bethke, 1996) and representative water samples from corehole Matalibong-25 (Mat-25). The degrees of mineral saturation in Mat-25 fluids suggest that: (a) illite would be actively precipitating from Mat-25 water; (b) K-feldspar, quartz and wairakite would be stable with respect to the fluid (i.e. unreactive if present); and (c) epidote, calcite, anhydrite and albite would be unstable in contact with the fluid (i.e. dissolving if present).

Quartz equilibrium suggests a downhole temperature of $260^{\circ} \mathrm{C}$ in corehole Mat-25, whereas $\mathrm{K}$-feldspar equilibrium suggests a temperature of about $266^{\circ} \mathrm{C}$. The proximity of a number of minerals to equilibrium suggests that small variations in water chemistry, temperature or pressure could produce changes in the mineral assemblage. Therefore, limited degrees of boiling or cooling, for example, could generate different phase assemblages. Using the 
React code, we were able to simulate the effects of isothermal and isoenthalpic boiling, conductive cooling and heating, and incorporation of condensed steam, on fluids from the Matalibong area at Tiwi. Predicted mineral stabilities were then used to identify key mineral indicators for each process. Table 1 summarizes our results.

Calcite and anhydrite precipitation were favored by conductive heating, while illite precipitation was favored when condensed steam was added to the reservoir fluid. Reconstructed downhole fluids from borehole Mat-25 are acidic, and are consistent with the presence of illite as the latest alteration mineral in veins. The processes of isothermal and isoenthalpic boiling could be differentiated from conductive cooling by the presence of epidote and/or calcite during boiling, and illite during cooling. Both boiling and cooling favored precipitation of quartz, K-feldspar, wairakite and pyrite. Ratios of $\mathrm{Na}$, $\mathrm{Cl}$ and $\mathrm{Br}$ in waters from the Matalibong area relative to seawater indicate a significant component of seawater in reservoir fluids.

Petrologic observations from Tiwi (Moore et al., 1997) agree well with simulation results. Our findings enable us to use more effectively mineral associations documented in core as indicators of the physical and chemical processes operative in geothermal systems over time.

Work on the scaling and fluid injection project at the Dixie Valley geothermal field commenced with the thermodynamic reconstruction of fluid chemistry under operating and subsurface conditions using chemical analyses provided by Dr. Fraser Goff at Los Alamos National Laboratory.

\section{FUTURE PLANS}

We plan to investigate several other isotopic systems that might be extremely useful at Coso. For example, $87 / 86 \mathrm{Sr}$ can be used for tracing solute origins and reactions, and $234 / 238 \mathrm{U}$ can be used for dating the time at which the water became thermal. We also plan to measure ${ }^{36} \mathrm{Cl},{ }^{129} \mathrm{I}$, and perhaps ${ }^{14} \mathrm{C}$ in Awibenkok waters in collaboration with UNOCAL.

We will explore more fully the relationships at Tiwi among fluid and mineral chemistry and the processes of boiling, heating, cooling and fluid mixing, especially with respect to seawater. We will measure and provide for variations in mineral composition, and account more fully for redox variations and the stability of sulfides.

Work on the Dixie Valley project will continue with simulations of the mixing of fluid streams and fluid-rock interactions during injection into the reservoir to define conditions causing adverse reactions, such as scale 
formation. This information can then be used to devise means of limiting adverse interactions.

\section{INDUSTRY INTEREST AND TECHNOLOGY TRANSFER}

Organization

Unocal Geothermal and

Power Operations

California Energy Company

Oxbow Power Services, Inc.

\author{
Type and Extent of Interest \\ relations between fluids and \\ alteration minerals at Tiwi \\ ${ }^{36} \mathrm{Cl} / \mathrm{Cl}$ isotopic study at Coso \\ scale formation and fluid \\ injection at Dixie Valley
}

\section{REFERENCES}

Bethke, C.M., 1996, Geochemical reaction modeling: Concepts and applications: Oxford Univ. Press, New York, 397 p.

Bruton, C.J., Moore, J.N. and Powell, T.S., 1997, Geochemical analysis of fluidmineral relations in the Tiwi geothermal field, Philippines: Proc. TwentySecond Workshop on Geothermal Reservoir Engineering, Stanford Univ., Jan. 27-29, 1997, in press.

Moore, J.N., Powell, T.S., Norman, D.I. and Johnson, G.W., 1997, Hydrothermal alteration and fluid-inclusion systematics of the reservoir rocks in Matalibong-25, Tiwi, Philippines: Proc. Twenty-Second Workshop on Geothermal Reservoir Engineering, Stanford Univ., Jan. 27-29, 1997, in press.

\section{CONTACTS}

DOE Program Managers:

Marshall Reed

Office of Geothermal Technologies, EE-12

U.S. Department of Energy

1000 Independence Ave., SW

Washington, DC 20585

Phone: (202) 586-8076

Fax: (202) 586-8185

Email: Marshall.Reed@hq.doe.gov

Peggy Brookshier

Office of Program Management

U.S. Department of Energy 
Idaho Operations Office

785 DOE Place, MS 1220

Idaho Falls, ID 83402

Phone: (208) 526-1403

Fax: (208) 526-6249

Email: BROOKSPA@INEL.GOV

LLNL:

Carol J. Bruton

Lawrence Livermore National Laboratory

L-219

P.O. Box 808

Livermore, CA 94550

Phone: 510-423-1936

Fax: 510-422-0208

Email: bruton1@llnl.gov

Table 1. Summary of tendency for mineral precipitation from Mat-25 water accompanying boiling, cooling, heating and addition of condensed steam. " $X$ " denotes a tendency for precipitation; a blank denotes no impact or tendency for dissolution. "decr." and "incr." refer to decreasing and increasing, respectively. Cond. cool = conductive cooling; IsoH and IsoT boil = isoenthalpic and isothermal boiling, respectively; Addtn. of gases = addition of condensed steam; Cond. heat = conductive heating.

\begin{tabular}{|l||l|l|l|l|l|l|l|l|l|}
\hline Process & Calcite & $\begin{array}{l}\text { Anhy- } \\
\text { drite }\end{array}$ & Quartz & $\begin{array}{l}\text { Kspar/ } \\
\text { Albite }\end{array}$ & $\begin{array}{l}\text { Mus- } \\
\text { covite }\end{array}$ & $\begin{array}{l}\text { Epi- } \\
\text { dote }\end{array}$ & $\begin{array}{l}\text { Waira- } \\
\text { kite }\end{array}$ & Pyrite & $\mathrm{pH}$ \\
\hline $\begin{array}{l}\text { Cond. } \\
\text { cool }\end{array}$ & & & $\mathrm{X}$ & $\mathrm{X}$ & $\mathrm{X}$ & & $\mathrm{X}$ & $\mathrm{X}$ & $\mathrm{decr}$ \\
\hline $\begin{array}{l}\text { IsoH } \\
\text { boil }\end{array}$ & $\mathrm{X}$ & & $\mathrm{X}$ & $\mathrm{X}$ & & $\mathrm{X}$ & $\mathrm{X}$ & $\mathrm{X}$ & incr. \\
\hline $\begin{array}{l}\text { IsoT } \\
\text { boil }\end{array}$ & $\mathrm{X}$ & & $\mathrm{X}$ & $\mathrm{X}$ & & $\mathrm{X}$ & $\mathrm{X}$ & $\mathrm{X}$ & incr. \\
\hline $\begin{array}{l}\text { Addtn. } \\
\text { of } \\
\text { gases }\end{array}$ & & & & & $\mathrm{X}$ & & & & decr. \\
\hline $\begin{array}{l}\text { Cond. } \\
\text { heat }\end{array}$ & $\mathrm{X}$ & $\mathrm{X}$ & & & & $\mathrm{X}$ & & & incr. \\
\hline
\end{tabular}




\title{
X-RAY VISUALIZATION OF CAPILLARITY EFFECTS IN PRESERVED CORE FROM THE GEYSERS
}

\author{
B.P. Bonner, J.J. Roberts and D. J. Schneberk \\ Experimental Geophysics Group MS L-201 \\ Lawrence Livermore National Laboratory \\ Livermore CA 94550
}

\section{KEY WORDS}

The Geysers, porosity, permeability, capillarity, water content, core analysis, physical properties

\section{BACKGROUND AND STATUS}

Understanding of the transport and storage of aqueous fluids are of fundamental importance to optimal management of any geothermal resource. Declining steam pressures at The Geysers provides particular motivation for obtaining more reliable estimates of water content to supplement inferences from models of reservoir performance. The scientific corehole, SB-15D, was drilled to completion in September 1994 in the central Geysers, near the site of the abandoned Geysers resort. It was acknowledged during the planning of this project that $\mathbf{x}$-ray imaging methods then available did not have sufficient sensitivity or resolution to determine water content in rocks with low porosities typical of Geysers matrix graywacke and argillite. Based on success in other difficult situations, it was decided to attempt application of high energy imaging methods developed for special purpose industrial imaging to the problem of detecting fluid in preserved core. Accomplishments have been described in the series of papers by Bonner, Roberts and colleagues referenced below, and analysis of Geysers data will be completed this year. This approach extends and supplements the primary water content measurement (Nuclear Magnetic Resonance) for a single depth, using core retrieved under pressure by Withjack and Durham, (1994).

\section{OBJECTIVES}

Obtaining direct measurements of water content and distribution was a primary goal of The Geysers Coring Project. Previous attempts to determine water content from Geysers core were not satisfactory, because of measurement artifacts and heterogeneous porosity which scales with core size. New methods had to be developed to obtain useful water saturation data.

\section{Technical Objectives}

- Obtain improved estimates of water content and distribution for the segments of core preserved at the SB-15D site.

- Investigate the relative importance of Darcy flow, capillarity and vapor phase diffusion in fluid transport from prompt scans of preserved core.

- Evaluate core preservation methods and $\mathrm{x}$-ray computed tomography for effectiveness in obtaining reliable hydrologic and geological properties for geothermal rocks. 
- Extensions of NMR measurements of water content from a single pressurized core to other depths by analysis of $\mathrm{x}$-ray attenuation for preserved core.

- New constraints on reservoir performance and lifetime at The Geysers.

\section{APPROACH}

A triple tube coring system was used successfully to recover preserved core with minimum disturbance of the in-situ water content and distribution. X-ray computed tomographs were made promptly to map three dimensional $\mathrm{x}$-ray attenuation in the jacketed core with resolution of $\sim 100$ micrometers. A high energy third generation scanning system was necessary to penetrate the aluminum coring tube and large diameter samples. These data were then used to infer water content and transport mechanisms at in-situ conditions.

\section{RESEARCH RESULTS}

A radial reconstruction of $x$-ray attenuation relative to air for core from $918 \mathrm{ft}$. in SB-15D is presented in Figure 1. This image is one of a series taken during a prompt scan done within $72 \mathrm{hrs}$. of drilling and is plotted as a negative with darker areas indicating higher attenuation and density. The thin ring around the core is the aluminum coring tube. The corresponding profile plotted below spans approximately a core diameter, $\sim 3.4$ in. The profile shows higher $\mathrm{x}$-ray attenuation near the core edges. Although the details of attenuation images such as these from various samples are clearly sample dependent, prompt scans from depths throughout the corehole consistently show higher attenuation in an annulus near the core edge. High attenuation near the core edges is consistent with fluid intrusion during drilling, and cannot be explained by any other plausible mechanism.

The characteristic profile shape seen in prompt scans (Figure 2a) is lost when core is dried slowly for a period of several weeks, as demonstrated in a scan taken of a slightly different section of the $918 \mathrm{ft}$ core. A scan of the core dried to ambient humidity $(\sim 30 \%)$ which implies a low but non zero water content is shown as Figure $2 b$. The left side of the profile is typical for the dry case, showing constant or decreasing attenuation near the core edge. The right side is unusual, showing a step change associated with a dry fracture--the sudden drop in attenuation---and change in lithology. The last profile, Figure $2 \mathrm{c}$, was taken in a nearby region after the sample was backfilled with water following vacuum evacuation. Saturation in this case was probably greater than $90 \%$. The profile shown is characteristic of the backfilled sample. The attenuation has become higher on average (Roberts et al., 1996), but more importantly for comparison with the prompt scans, shows a decrease near the edges of the core. Although care was taken to minimize drying of the backfilled sample before and during scanning, some dryout apparently occurred, producing lower attenuation near the core edges. It is particularly significant to note that this did not occur at the drill site because air trapped in the sealing operation saturated with water vapor as the core cooled from reservoir to ambient temperature in the sealed tube. Core preservation methods employed in the field generally prevented dryout (Hulen and Nielson, 1994), and made it possible to observe profiles indicative of mud intrusion. Attenuation variability in this core segment after backfilling indicates that porosity gradients exist on the core scale, and may be indicative of graded beds in graywackes interbedded with metashales at this depth.

Withjack and Durham, 1994, report results of a successful effort to recover pressurized core near the end of coring (runs 69,1423 ft and 88, $1600 \mathrm{ft}$ ) in SB-15D. Core was recovered, and then frozen to maintain water content and analyzed for water content and mud contamination using Nuclear Magnetic Resonance spectroscopy and a tritium tracer. 
Tritium contamination consistent with fluid infiltration was detected and correlated with time of exposure to the drilling fluid for run 69, which was detained downhole for $24 \mathrm{hrs}$. waiting for formation pressure to recover. NMR measurements for plugs from the center of core from run 88 , which was recovered rapidly, showed low water saturations estimated to be from 3 to $13 \%$. Independent measurements of pore size distribution for SB-15D rocks indicate that pores smaller than 10 microns are common in these rocks. Both of these observations are consistent with flow into the core driven by high capillary suctions in-situ.

$\mathrm{X}$-ray CT results provide indirect evidence that low water saturations occur throughout the cored interval in SB-15D. Attenuation profiles characteristic of imbibition of drilling fluid occur to some degree in all of the prompt scans of preserved core, suggesting that strong capillary suctions consistent with low saturations are common in rocks collected from an area in The Geysers with a long production history.

\section{FUTURE PLANS}

Measurements of porosity, and dry and backfilled x-ray attenuations for selected segments of SB-15D core will be made to determine if water saturation gradients can be detected in the prompt scans. Samples collected near the lost circulation zone, a presumed steam entry during production of SB-15, will be the main focus of study. X-ray CT scans of core from other DOE sponsored coring projects will be made as needed to evaluate geological and hydrlogical properties.

\section{INDUSTRY INTEREST AND TECHNOLOGY TRANSFER}

Organization Type of Interest

\begin{tabular}{|l|l|}
\hline Cal Pine & reservoir optimization strategies \\
\hline Unocal & reservoir hydrological properties \\
\hline
\end{tabular}

\section{REFERENCES}

Bonner, Brian P., J. J. Roberts and D. L. Schneberk, Determining water content and distribution in reservoir graywacke from the northeast Geysers with $\mathrm{x}$-ray computed tomography, Trans. Geothermal Resources Council, 18, 305-310, 1994.

Bonner, Brian P, J. J. Roberts, D. L. Schneberk, A.. Marsh and C. Ruddle, X-ray tomography of preserved core from The Geysers scientific corehole, 20th Workshop on Geothermal Reservoir Engineering, Stanford University, 1995.

Hulen, J. B. and D. L. Nielson, Sample handling, field procedures, and curation guidelines for The Geysers Coring Project, University of Utah Research Institute Report, ESL-94002-TR,1994.

Roberts, J. J., Bonner, B. P., A. G. Duba and D. J. Schneberk, Physical properties of preserved core from The Geysers scientific corehole, SB-15D, 21st Workshop on Geothermal Reservoir Engineering Proceedings, Stanford University, 313-317, 1996. 
Withjack, E. M., and J. R. Durham, Special core analysis, Geysers SB-15 coring project, Unocal Geothermal, Internal Memorandum resubmitted as Final Report to Idaho National Engineering Laboratory, 1994.

Contacts:

Brian Bonner

Lawrence Livermore National Laboratory

7000 East Ave., L-20'

P.O. Box 808

Livermore CA 94550

Phone: $510-422-7080$

Fax: (510) 423-1057

Email: bonner1@llnl.gov

Marshall Reed

Office of Geothermal Technologies, EE-12

U.S. Department of Energy

1000 Independence Ave., SW

Washington, DC 20585

Phone: (202) 586-8076

Fax: (202) 586-8185

Email: Marshall.Reed@hq.doe.gov

Peggy Brookshier

Office of Program Management

U.S. Department of Energy

Idaho Operations Office

785 DOE Place, MS 1220

Idaho Falls, ID 83402

Phone: (208) 526-1403

Fax: (208) 526-6249

Email: BROOKSPA@INEL.GOV 


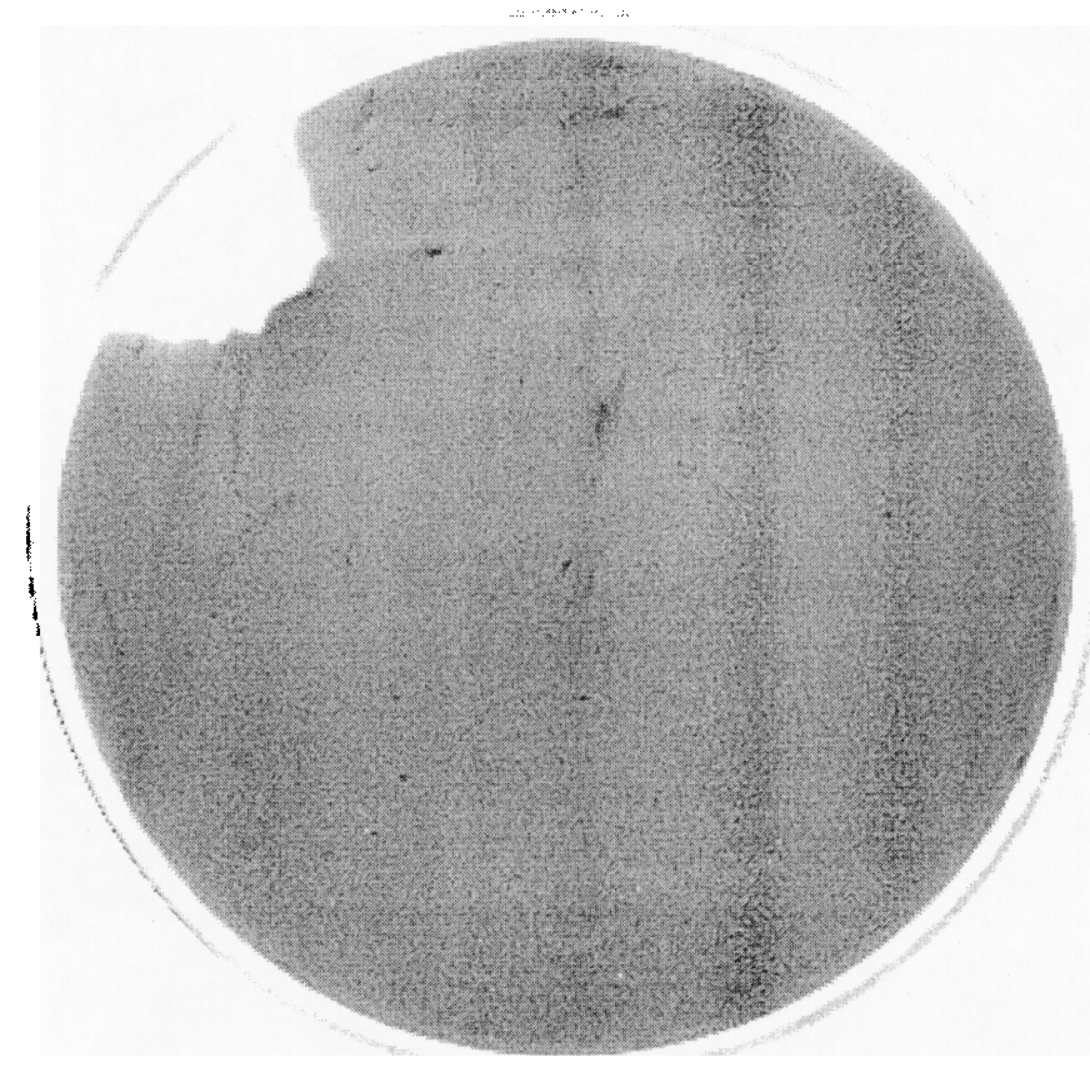

Figure 1a. A radial slice mapping relative $\mathrm{x}$-ray attenuation for SB-15 D core, $918 \mathrm{ft}$. Darker shading indicates higher relative attenuation, consistent with imbibition of drilling fluid. The scan was made promptly after drilling, within 72 hours.

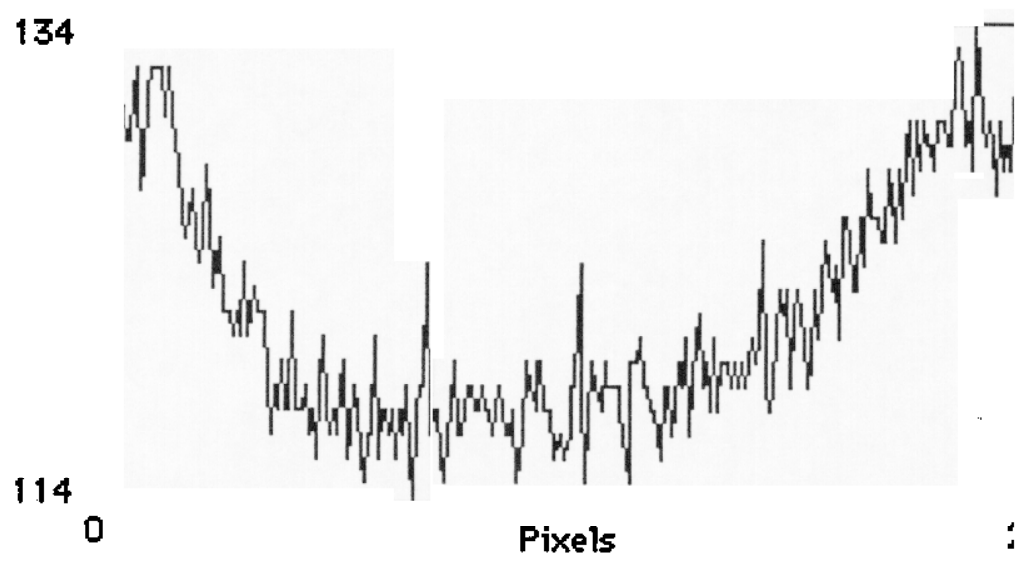

Figure $1 \mathrm{~b}$. Relative $\mathrm{x}$-ray attenuation for a typical diameter for the $918 \mathrm{ft}$ sample shown above. 


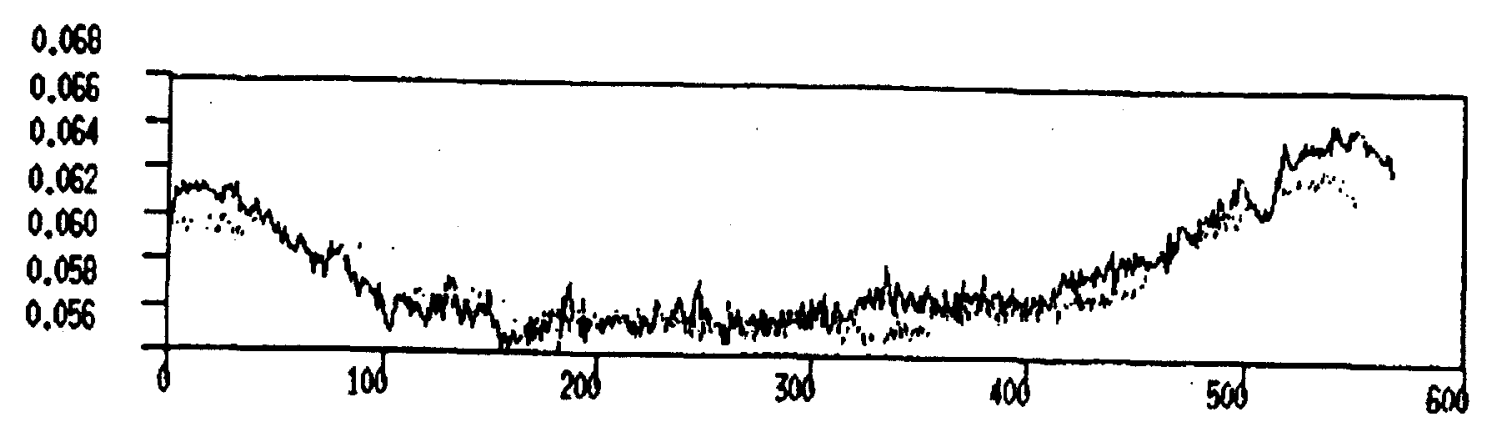

(a)

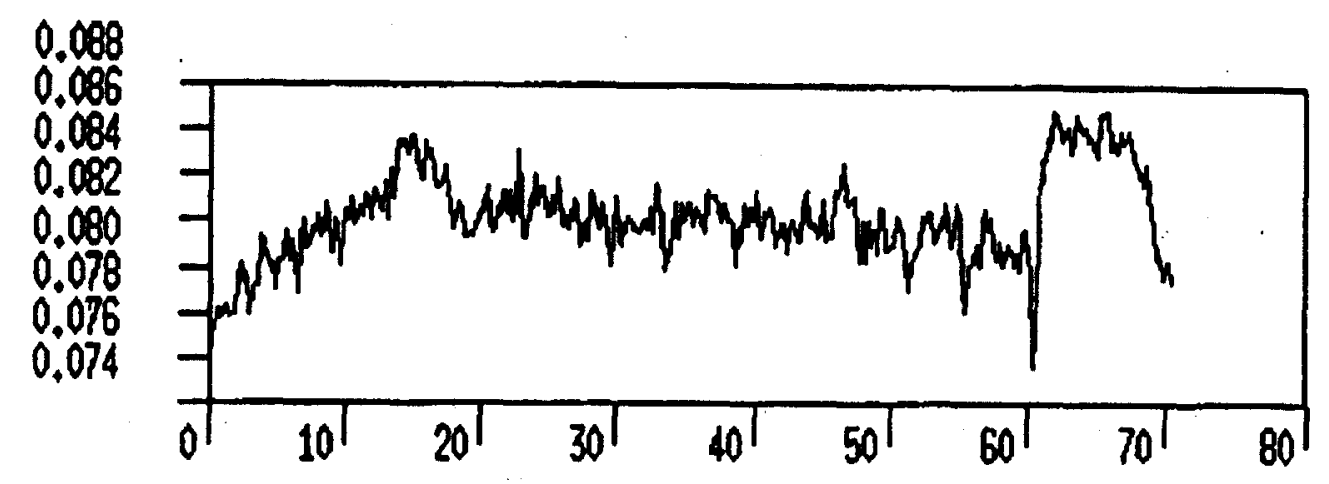

(b)

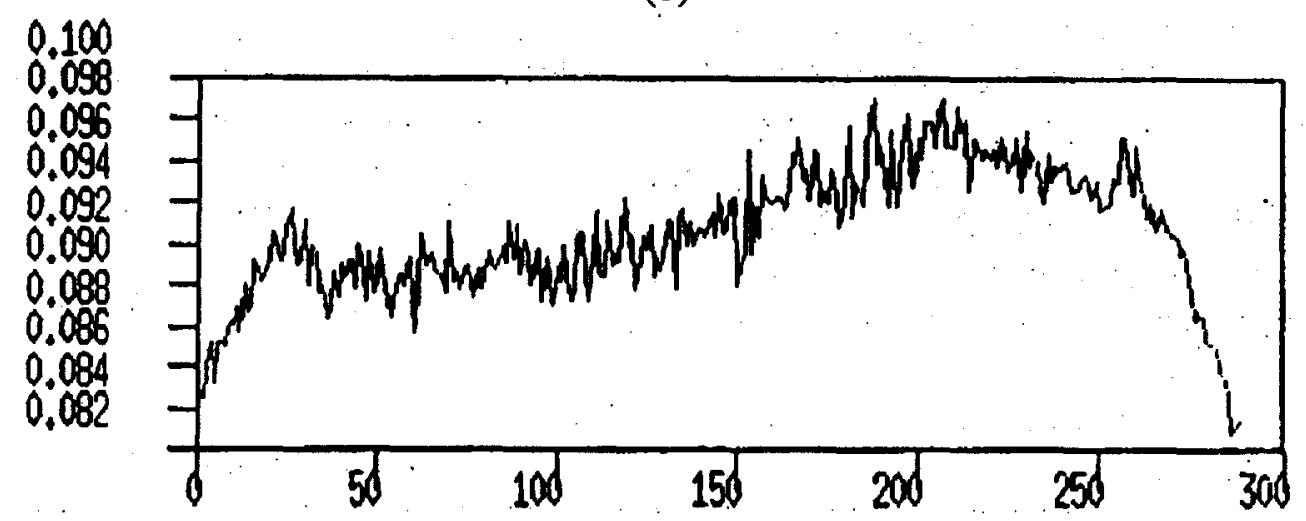

(c)

Figure 2. Radial scans of $\mathrm{x}$-ray attenuation for slightly different areas of the $918 \mathrm{ft}$. core from SB-15D. Scan conditions were promptly after core recovery (a), after drying at ambient humidity (b) and after vacuum evacuation and backfilling with water (c). 


\title{
FRACTURE MAPPING IN GEOTHERMAL FIELDS WITH LONG-OFFSET INDUCTION LOGGING
}

\author{
Michael Wilt and Paul Kasameyer \\ Lawrence Livermore National Laboratory (LLNL)
}

Shinji Takasugi
Geothermal Energy Research and Development (GERD)

Ki Ha Lee and Marcelo Lippmann
Lawrence Berkeley National Laboratory (LBNL)

Toshihiro Uchida

New Energy and Industrial Technology Organization (NEDO)

\section{KEY WORDS}

borehole logging, fracture detection, electrical resistivity

\section{PROJECT BACKGROUND AND STATUS}

The mapping of producing fractures in a geothermal field is an extremely important technical objective in field development. Locating, orienting, and assessing producing fractures can guide drilling programs and optimize the placement of production and injection wells. This results in fewer dry holes and substantial cost savings in field development. In 1994, NEDO and GERD designed a long-offset borehole induction resistivity tool capable of surviving the high temperatures (Sato et. al., 1996) encountered in geothermal wells. This Multi-Frequency Array Induction Logging (MAIL) tool was then built by an American contractor, Electromagnetic Instruments. Several characteristics of this device make it ideal for detecting producing fractures. Whereas commercial induction logging devices have source-receiver separations of 1 $\mathrm{m}$, this tool has multiple sensors with separations up to $8 \mathrm{~m}$, allowing for deeper penetration and the ability to straddle fracture-induced washout zones in boreholes. In addition, the tool's three-component measurement capability makes it possible to map the strike and inclination of nearby fractures and other three-dimensional structures. This, in turn, allows for accurate projection of these structures into the space between wells. This tool was initially tested in the WD-1 well at the Kokkanda geothermal field in central Japan in 1995. The tool was operated at temperatures in excess of $190^{\circ} \mathrm{C}$ at depths exceeding $2.6 \mathrm{~km}$ (Sato et al., 1996; Uchida et al., 1996). This test was designed to identify low-resistivity zones associated with through-going fractures, and the results were only partially successful in this task. In order to evaluate and demonstrate the value of this tool, we initiated a project in 
FY1996 to test it in the lab, in well-characterized wells, and in geothermal systems.

\section{PROJECT OBJECTIVES}

The objective of this project was to determine the feasibility of long-offset induction logging for fracture mapping in geothermal systems.

\section{Technical Objectives}

- Develop and test numerical models, of the response of borehole induction logs, and calibrate the existing longoffset induction logging tool, MAIL, in geothermal systems.

\section{Expected Outcomes}

- Long-offset induction logging could have significant consequences for geothermal field development because the orientation of producing fracture zones could potentially be determined from these measurements; it may also be possible to locate nearby producing zones from "near miss" exploration boreholes.

\section{APPROACH}

Our approach is to develop and test numerical models, work with GERD of Japan to conduct a series of field tests with their MAIL tool. From these models and results, we can determine the feasibility of fracture mapping from single-hole measurements and the effectiveness of the MAIL design.

\section{Description of the MAIL Tool}

The MAIL tool was designed for high resolution mapping of the conductivity structure in geothermal wells. A schematic drawing of the tool (Figure 1) indicates that it has a multifrequency transmitter section in one end and an array of induction coil and fluxgate sensors distributed throughout the rest of the tool. Five vertically oriented induction coil sensors are spaced 4, 5, 6, 7, and $8 \mathrm{~m}$ from the transmitter; two horizontal field sensors are situated at 7.5 $\mathrm{m}$; and a three-component fluxgate magnetometer lies $3 \mathrm{~m}$ from the source. The fluxgate magnetometers are used for tool orientation. The transmitter may operate at $3,12,24$, and $42 \mathrm{kHz}$, but it is more powerful at the lower frequencies.

Signal detection, synchronous stacking, and analog-to-digital (A/D) . conversion are accomplished within the tool before transmission to a personal computer (PC)-controlled surface station. Software on the PC is used 
to control the data collection sequence, apply calibration corrections, and display and store results.

The tool has also been hardened for a high-temperature, high-pressure environment. Special temperature-resistant polycarbonate materials house the sensors, and a high-vacuum stainless-steel dewar protects electronic components so that the tool can withstand downhole temperatures of $260^{\circ} \mathrm{C}$ for up to 12 hours. This configuration makes the tool suitable for use in many geothermal wells. An oil compensation system is used for pressure maintenance to depths of up to $4 \mathrm{~km}$.

Several characteristics of this device make it ideal for detecting producing fractures. The long source-receiver offsets of the induction coil sensors make it useful for detecting structure well away from the borehole. Typical induction logging devices have source-receiver separations of $1 \mathrm{~m}$, whereas this device has separation up to $8 \mathrm{~m}$ allowing up to $10-\mathrm{m}$ penetration into the formation. In addition, many producing fractures in geothermal wells are associated with washout and lost-circulation zones, thereby making conventional (short-offset) logging ineffective. Long-offset sensors, which easily straddle such zones, are affected less by nearby well structure. In addition, the multiple sensors and frequencies allow for building radially and azimuthally varying images of the resistivity with depth. Finally, the threecomponent measurements also make it possible to map the strike and inclination of fractures or other heterogeneities. This, in turn, allows for the accurate projection of these structures into the space between wells.

\section{Performance Tests}

We thoroughly tested and calibrated the logging tool in collaboration with the manufacturer, Electromagnetic Instruments, Inc, (EMI) this process improved the performance of the tool.

Then, a performance test of the tool was made at the Lost Hills oil field in central California, where Mobil Exploration and Production U.S. operates a shallow steam flood for enhanced oil recovery. Several steam injectors and fiberglass-cased observation wells are available at this site for making measurements. This site was chosen for its well-characterized structure and the presence of a high-temperature zone near the observation well.

We deployed the tool in a fiberglass-cased observation well located $30 \mathrm{~m}$ from a steam injector. The observation well has several nonuniform, hightemperature zones due to the recent steam flood in addition to evidence of a high-conductivity zone adjacent to the well (probably pyrite from gas evolution). In the past, we used this and a companion observation well for crosshole electromagnetic studies that tracked the injected steam plume for several years (Wilt et al., 1995). We therefore have a good idea of the electrical resistivity structure in the region between the boreholes. 


\section{RESEARCH RESULTS}

In Figure 2a, we show the commercial induction resistivity log from the borehole collected immediately after drilling in 1992 and the MAIL 5-m offset $\log$ from December 1996. The two responses are similar in the upper reaches of the well but differ below $60 \mathrm{~m}$, where the resistivity measured with the MAIL tool is significantly less than the commercial log. This difference is primarily due to the high-temperature zone in the borehole (in excess of $130^{\circ} \mathrm{C}$ ) caused by the nearby steam injector. The replacement of insulating oil with hot water and steam is consistent with the more than $50 \%$ reduction in resistivity observed with the logs. The MAIL log is smoother than the older induction log because of the longer source-receiver offsets.

In Figure 2b, we plot the horizontal field responses from the MAIL log in the same borehole. Note that for a homogeneous or horizontally layered medium, the horizontal fields from a single borehole logging device are zero. These fields are nonzero only where the formation adjacent to the borehole is heterogeneous. They may therefore indicate a fracture zone or a nonsymmetrical structure, such as a steam zone. In this case, the horizontal fields display a crossover anomaly with peaks corresponding to the boundaries of the high-temperature zone. This structure is consistent with a low-resistivity zone (steam plume) that is more pronounced east of the well, or toward the steam injector. Note that these data have not been corrected for tool rotation, which is necessary before the data can be interpreted.

\section{FUTURE PLANS}

We are presently fitting the field data with three-dimensional electrical resistivity models to determine the geometry of the low-resistivity zones adjacent with the wellbore. We will use two-dimensional data resistivity models obtained from crosshole electromagnetic studies for the initial guess models.

Within the next year, the data set collected will be further analyzed, and the results will be published in a national journal. The tool is also scheduled for future deployments at several geothermal fields worldwide. These include test at the Los Alamos Fenton Hill site, the Geysers, and at an operating field in Indonesia.

\section{INDUSTRY INTEREST AND TECHNOLOGY TRANSFER}

\begin{tabular}{ll} 
Organization & Type and Extent of Interest \\
\hline Unocal geothermal & $\begin{array}{l}\text { Interested in determining if tool } \\
\text { useful for fracture or injection } \\
\text { is }\end{array}$ \\
matection. Interested in \\
advanced versions of tool.
\end{tabular}




\section{REFERENCES}

Sato, T., Osato, K., Takasugi, S., and Uchida, T., EMI, 1996, Development of the Multi-Frequency Array Induction Logging (MAIL) Tool. Geothermal

Resources Council Transactions 20(9), 637-642.

Uchida, T., Akaku, K., Sasaki, M., Kamenosono, H., Doi, N., and Miyazaki, S., 1996, Recent Progress of NEDO's "Deep-Seated Geothermal Resources Survey" project, Geothermal Resources Council Transactions 20(9), 643-648. Wilt, M., Lee, K., Alumbaugh, D., Morrison, H. F., Becker, A., Tseng, H. W., and Torres-Verdin, C., 1995, Crosshole Electromagnetic Tomography-A New technology. for Oil field Characterization. the Leading Edge of Exploration, published by the Society of Exploration Geophysicists. p173-177.

\section{CONTACTS}

Paul Kasameyer

Lawrence Livermore National Laboratory

7000 East Ave., L-208

P.O. Box 808

Livermore, CA 94550

Phone: (510) 422-6487

Fax: (510) 422-3925

Email: kasameyer@llnl.gov

Ki Ha Lee

Lawrence Berkeley National Laboratory

1 Cyclotron Rd

Berkeley, CA, 94720

Phone: (510) 486-7468

Fax: (510) 486-5686

Email: kiha@csem.lbl.gov

Marshall Reed

Office of Geothermal Technologies, EE-12

U.S. Department of Energy

1000 Independence Ave., SW

Washington, DC 20585

Phone: (202) 586-8076

Fax: (202) 586-8185

Email: Marshall.Reed@hq.doe.gov

Peggy Brookshier

Office of Program Management

U.S. Department of Energy

Idaho Operations Office

785 DOE Place, MS 1220

Idaho Falls, ID 83402 
Phone: (208) 526-1403

Fax: (208) 526-6249

Email: BROOKSPA@INEL.GOV

Gladys Hooper

Geothermal Division EE-12

U.S. Department of Energy

1000 Independence Ave., SW

Washington, DC 20585

Phone: 202-586-1146

Fax: 202-586-8185

Email: GLADYS.HOOPER@hq.doe.gov 


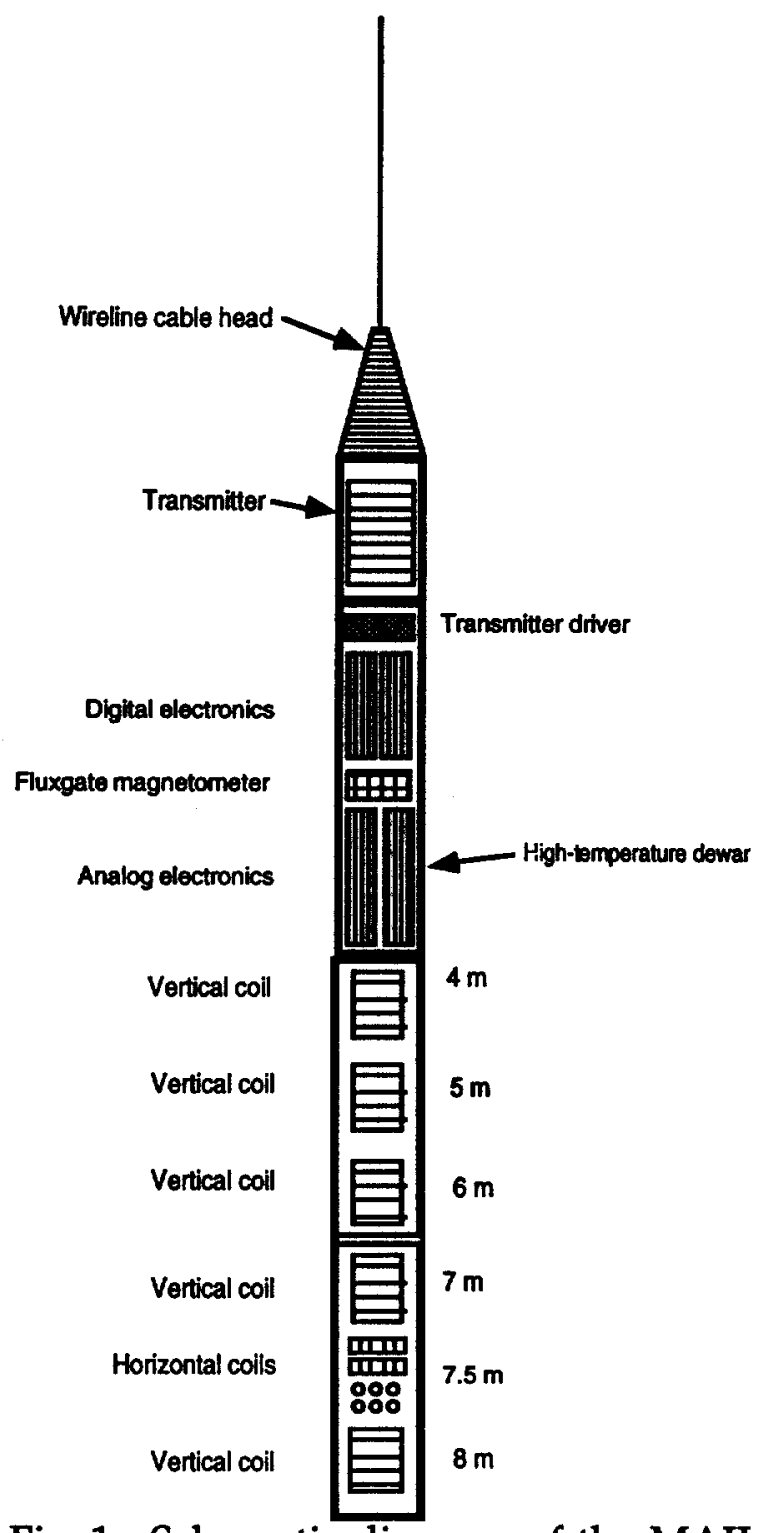

Fig. 1. Schematic diagram of the MAIL long-offset induction logging device. 
(a) Apparent Resistivity Log

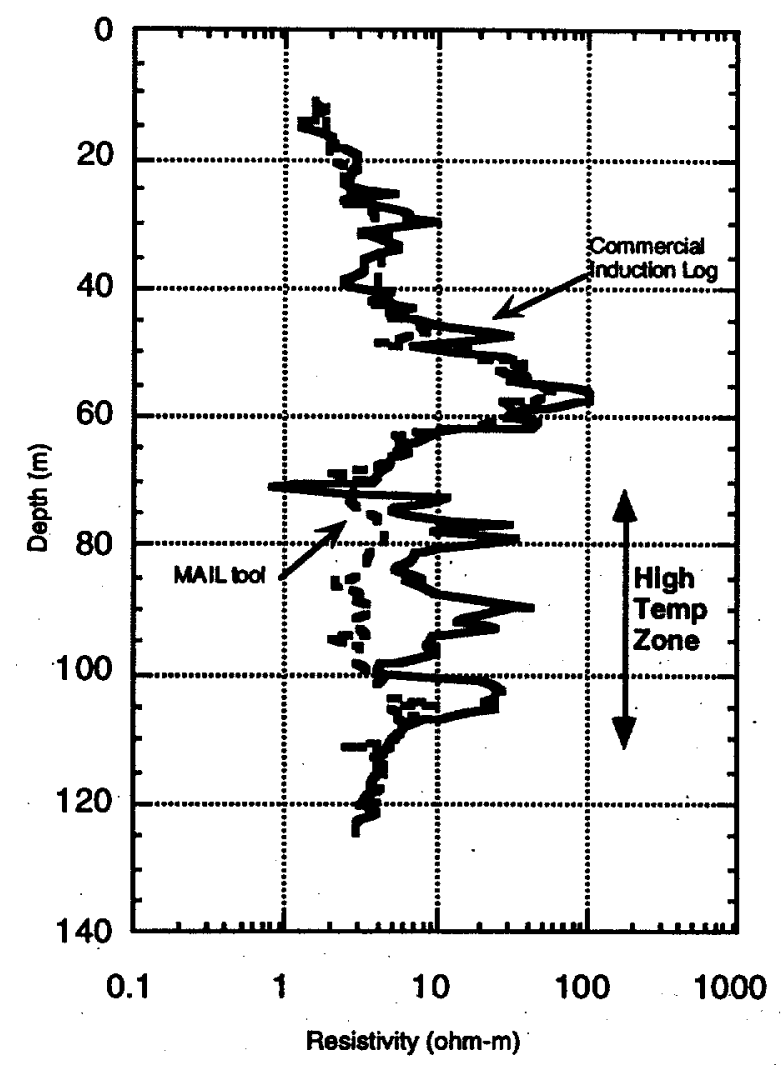

(b) Horizontal Fleld Log

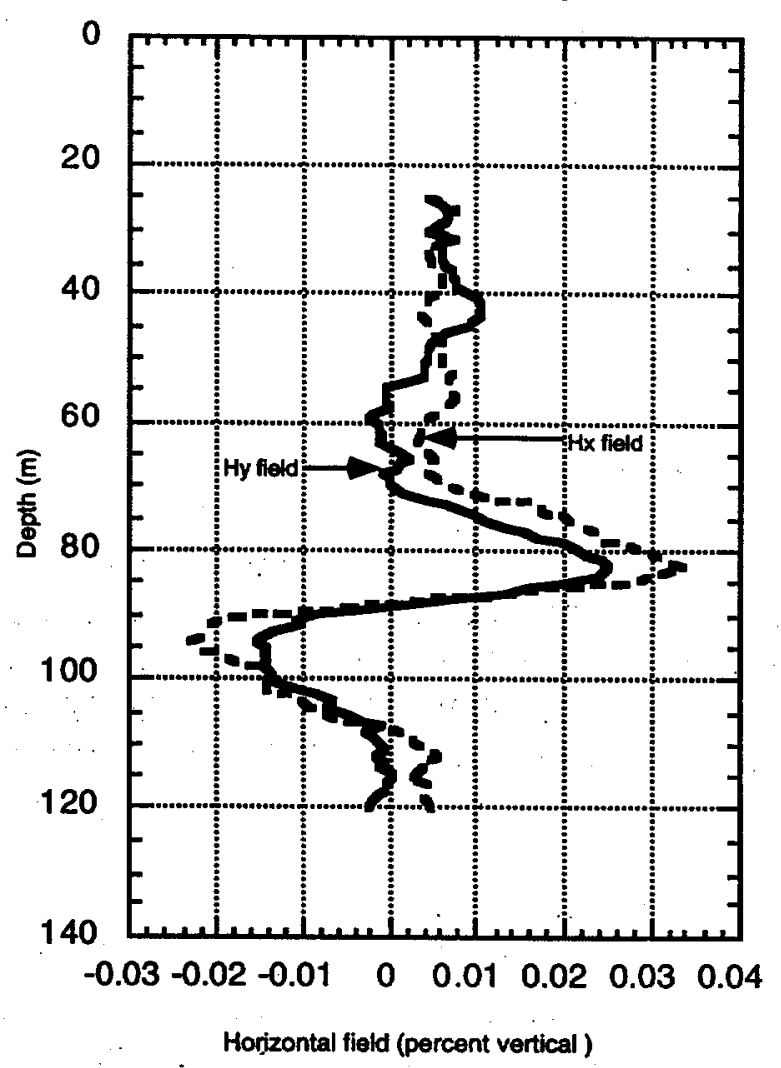

Fig. 2. (a) Comparison of apparent resistivity logs measured with the MAIL tool and conventional induction logging data in the same borehole. Note: the MAIL data was collected after steam injection. (b) Horizontal magnetic fields from the MAIL in the same borehole. 
Reduction of operating and maintenance costs at geothermal power plants

Carol J. Bruton, Joseph Rard, Charles Stevens

KEY WORDS

operating and maintenance costs, $\mathrm{H}_{2} \mathrm{~S}$ abatement, $\mathrm{H}_{2} \mathrm{~S}$ stack emissions

\section{PROJECT BACKGROUND AND STATUS}

This project commenced in the latter half of FY1996 in response to the economic necessity of reducing the costs of geothermal power production, especially in light of the effects of deregulation on the power generation industry. To bridge the gap between national laboratory capabilities and industry needs, we are identifying established expertise and technology to help to reduce the chemical costs associated with operations and maintenance of geothermal power plants. Initial work has been focused at The Geysers to immediately address real-life problems, but our findings will be applicable to other power plants as well.

Power plants at The Geysers must limit the release to the atmosphere of hydrogen sulfide $\left(\mathrm{H}_{2} \mathrm{~S}\right)$ that is contained in produced geothermal steam. We initially focused on two problems related to that need: reduction of chemical processing costs and measurement of emissions. At present, Pacific Gas and Electric (PG\&E) uses two major technologies to abate hydrogen sulfide: (1) oxidation using the iron-HEDTA complex, an iron chelate, and (2) use of the Stretford process which involves oxidation using a vanadium oxide catalyst. The first technology requires use of a fairly expensive chemical reagent, and the second produces large amounts of an alkaline salt cake that contains sulfur in a variety of chemical forms. PG\&E is interested in finding less expensive, alternate reagents for process 1 , removing elemental sulfur from the Stretford solutions (which has some market value), and destroying thiosulfate ions present in these mixtures. Results obtained in this study will be applicable to other geothermal fields with $\mathrm{H}_{2} \mathrm{~S}$ problems.

There is presently no way to continuously monitor $\mathrm{H}_{2} \mathrm{~S}$ emissions from cooling towers to ensure air quality compliance and control the addition of necessary $\mathrm{H}_{2} \mathrm{~S}$ abatement chemical additives upstream. PG\&E technicians currently measure $\mathrm{H}_{2} \mathrm{~S}$ emissions using portable analyzers at 36 sample points per stack on a monthly basis, upon which iron chelate demand is based.

\section{PROJECT OBJECTIVES}

Reductions in chemical costs in power plants will be pursued regarding: a) improved chemical processes associated with $\mathrm{H}_{2} \mathrm{~S}$ abatement techniques and b) use of Cross Dispersive Infrared Spectrometry, a new type of infrared 
optical technology developed for non-proliferation verification, to provide accurate, reliable, continuous $\mathrm{H}_{2} \mathrm{~S}$ measurements needed to continuously monitor cooling tower emissions.

Technical Objectives

- determine the mode of decomposition of the Stretford solution upon acidification; seek improved ways of extracting elemental sulfur from the Stretford solutions; and seek ways of removing thiosulfate ions from these solutions

- seek less-expensive alternatives to the iron-HEDTA chelate oxidation technology

- demonstrate the utility of continuous infrared spectral monitoring of $\mathrm{H}_{2} \mathrm{~S}$ emissions from cooling towers

\section{Expected Outcomes}

- Reduce the cost of iron chelate, the most expensive aspect of $\mathrm{H}_{2} \mathrm{~S}$ abatement at The Geysers. Replenishment of chelating agent costs PG\&E $\$ 4$ million per year. PG\&E currently uses a fixed amount of chelate and cannot adapt for changing input fluid chemistries or variations in plant operation.

- Real time monitoring for $\mathrm{H}_{2} \mathrm{~S}$ stack emissions could save $\$ 300 \mathrm{~K}$ per year by allowing PG\&E to adjust the amount of chelating agent that has to be added to achieve balance with the $\mathrm{H}_{2} \mathrm{~S}$ in solution.

- Development of an improved method of removing unwanted sulfur species from Stretford solutions would be equally applicable to 114 Stretford units used throughout the world that have similar problems.

\section{APPROACH}

At the present time, we are collaborating with personnel from PG\&E who are supplying us with information and fluid samples from The Geysers and accompanying us on site visits to constrain our laboratory measurements and experiments, and to properly design the spectrometer system according to onsite conditions.

\section{RESEARCH RESULTS}

We obtained fluid samples from PG\&E of the effluent solutions from the two currently used technologies for $\mathrm{H}_{2} \mathrm{~S}$ abatement at The Geysers and characterized their ionic and elemental composition. Results indicate that much of the sulfur is present as sodium polysulfide, sulfate, and thiosulfate ions in the Stretford solutions, and as sulfate, thiosulfate and other oxysulfur ions in the iron chelate treated solutions. The presence of polysulfides and the fact that most of the sulfur exists in this chemical form was of special 
interest, and will impact chemical treatments for $\mathrm{H}_{2} \mathrm{~S}$ abatement. In comparing different techniques for sulfur analysis, it was determined that the iodometric titration method will not detect sulfate ion, nor elemental sulfur at acidic $\mathrm{pH}$.

Assessments of the application of infrared spectroscopy, discussions with PG\&E personnel and site visits suggest that direct line-of-sight measurements of $\mathrm{H}_{2} \mathrm{~S}$ through a cooling tower, although the most direct, may be problematic owing to reduced transmissivity through cooling tower "fog". A mid-infrared laser will be tested which may have improved transmission through fog: Other options that are being considered include multiple sample ports located inside the cooling towers that continuously withdraw vapors to a common analysis location, and alternately, headspace analysis of the condensate just before entering the cooling towers.

The continuous $\mathrm{H}_{2} \mathrm{~S}$ monitor project is unique in that it is affected by spectrometer availability. The proof of principal experiments will use an existing remote sensing spectrometer and will have to be scheduled around existing commitments for that instrument.

\section{FUTURE PLANS}

We plan to complete the quantitative chemical analyses of the Stretford and iron chelate effluent, determine the mode of decomposition of the Stretford solution upon acidification, seek improved ways of extracting elemental sulfur and thiosulfate ions from the Stretford solutions, and identify less-expensive alternatives to the iron chelate oxidation technology.

We will measure the absorption of $\mathrm{H}_{2} \mathrm{~S}$ in the laboratory to establish measurement accuracy and fabricate an optical system that will allow us to measure headspace gases from the condensate pipe leading to the cooling towers. We will conduct on-site experiments at The Geyser power plants that will measure the $\mathrm{H}_{2} \mathrm{~S}$ concentrations in the condensate stream at various locations along the pipe leading to various cooling towers.

\section{INDUSTRY INTEREST AND TECHNOLOGY TRANSFER}

Organization

PG\&E

\section{CONTACTS}

DOE Program Managers:

Gladys Hooper

Geothermal Division EE-12

U.S. Department of Energy

1000 Independence Ave., SW
Type and Extent of Interest $\mathrm{H}_{2} \mathrm{~S}$ abatement techniques, $\mathrm{H}_{2} \mathrm{~S}$ emission monitor 
Washington, DC 20585

Phone: 202-586-1146

Fax: 202-586-8185

Email: GLADYS.HOOPER@hq.doe.gov

Marshall Reed

Office of Geothermal Technologies, EE-12

U.S. Department of Energy

1000 Independence Ave., SW

Washington, DC 20585

Phone: (202) 586-8076

Fax: (202) 586-8185

Email: Marshall.Reed@hq.doe.gov

Peggy Brookshier

Office of Program Management

U.S. Department of Energy

Idaho Operations Office

785 DOE Place; MS 1220

Idaho Falls, ID 83402

Phone: (208) 526-1403

Fax: (208) 526-6249

Email: BROOKSPA@INEL.GOV

LLNL:

Carol J. Bruton

Lawrence Livermore National Laboratory

L-219

P.O. Box 808

Livermore, CA 94550

Phone: 510-423-1936

Fax: 510-422-0208

Email: bruton1@llnl.gov 


\title{
ELECTRICAL PROPERTIES OF ROCKS AT GEOTHERMAL-RESERVOIR CONDITIONS
}

\author{
Al Duba, Jeffery J. Roberts, Brian P. Bonner \\ Lawrence Livermore National Laboratory, P.O. BOX 808, Livermore, CA \\ 94551
}

KEY WORDS: ELECTRICAL RESISTIVITY, RESISTIVITY OF SATURATED ROCKS, RESISTIVITY OF STEAM-SATURATED ROCKS

PROJECT BACKGROUND AND STATUS

The electrical properties of reservoir rocks are important for the establishment of a database for interpretation of borehole data and surface EM measurements and for the information that can be obtained regarding the physical and transport properties of the rock/water system. We have measured the electrical properties of greywackes, meta-shales and argillites from Geysers corehole SB-15D at pressures up to 100 bars (confining pressure) and temperatures between 20 and $150^{\circ} \mathrm{C}$. Some of this work was reported at workshops at Stanford and Santa Rosa (Roberts et al., 1996a,b) and published in the proceedings of the Stanford Workshop (1996b).

The project started in FY 96 and should be completed in FY 98. We have collected enough preliminary data on the electrical resistivity of these rocks as the pore fluid begins to boil to design and modify the apparatus in order to make the necessary measurements more accurately and efficiently.

\section{PROJECT OBJECTIVES}

The general objective of the project is to collect accurate data on the electrical resistivity of geothermal rocks in a laboratory environment which closely simulates that expected in the geothermal-reservoir environment. Important parameters to control are pore pressure, confining pressure, temperature and fluid salinity.

Technical Objectives

- Measure electrical resistivity of reservoir-fluid-saturated rocks as steam is produced in laboratory simulations of reservoir conditions.

- Construct a state-of-the-art system for control of pore pressure and confining pressure while steam is being generated in a geothermalreservoir rock on which electrical resistivity measurements are being made.

- Determine the effect of pore-size distribution on boiling-point elevation in these cores.

Expected Outcome 
- Laboratory data which permit delineation of steam-saturated, geothermal-reservoir rocks from field surveys.

- A better understanding of the effect of pore-size distribution on boiling in geothermal-reservoir rocks.

\section{APPROACH}

Electrical resistance was measured on rock cores from borehole SB15-D in the Geysers geothermal area to temperatures up to $150^{\circ} \mathrm{C}$ and $10 \mathrm{MPa}(100$ bars). Resistance was measured as a function of temperature and pressure in the water-saturated state initially. Then, resistance was measured as pressure was decreased in order to induce to boiling, as indicated by a sudden increase in resistance. Measurements were made with and without pore pressure control. Electrical resistivity was calculated from the resistance and geometry of the core.

\section{RESEARCH RESULTS}

Pore pressure not explicitly controlled.

Increasing pressure had only a small effect on the electrical resistivity for measurements made at $20^{\circ} \mathrm{C}$. An increase in pressure up to -90 bars increased the resistivity only slightly, by $\sim 0.05 \log$ units. Increasing temperature had a large effect on the electrical resistivity of all samples. At a pressure of $\sim 10$ bars, increasing temperature from 20 to $145^{\circ} \mathrm{C}$ resulted in a decrease in the electrical resistivity of nearly an order of magnitude.

Lowering the pressure when the samples were at temperatures of $\sim 145^{\circ} \mathrm{C}$ produced some interesting effects. Although the pore pressure was not controlled explicitly, lowering the confining pressure lowered the pore pressure enough so that the steam field was entered. At $145^{\circ} \mathrm{C}$ the electrical resistivity increases by about 2 orders of magnitude as confining pressure is decreased from 6 to 4 bars (Figure 1).

Pore pressure controlled.

One experiment was successfully run controlling pore pressure independently of confining pressure. The duration of the experiment was about three months. This particular sample was an argillite or metashale rather than a metagraywacke and it had a porosity of 3.4\%. Despite differential pressures in excess of 15 bars, there was never observable flow through the sample, even in the steam stability field, for periods up to several days. This is consistent with the low matrix-permeability of $10^{-21} \mathrm{~m}^{2}$ (nano-Darcy) reported for core from this hole (Persoff and Hulen, 1996). Figure 2 shows the resistivity of the sample as a function of temperature at a confining pressure of $\sim 40$ bars. Pore pressure was controlled during this experiment. One end of the sample was held to a pore pressure below $1 \mathrm{bar}$, which allowed boiling to occur at higher temperatures reached in the experiment. As seen in the plot, the resistivity at $20^{\circ} \mathrm{C}$ is near $600 \Omega \mathrm{m}$, and reaches a minimum of $100 \Omega \mathrm{m}$ between 100 and $110^{\circ} \mathrm{C}$. At higher temperatures the resistivity again increases, due to the formation of steam. At $145^{\circ} \mathrm{C}$ the resistivity is nearly the same as at $20^{\circ} \mathrm{C}$. An important point is that, in the absence of a system where fracture properties dominate the electrical properties, care must be taken with the inversion and interpretation 
of field data since, within a narrow resistivity range, a transition from liquid-dominated to steam-dominated conditions exists.

Figure 3 is a plot of the resistivity as a function of pore pressure at $147^{\circ} \mathrm{C}$ and a confining pressure of 50.5 bars. Pressure was varied on the 'downstream' or low pore pressure end of the sample, while the pore pressure on the other end was held to $\sim 15.3$ bars. Only the downstream pressure was varied because of the low permeability of the sample. This plot shows an interesting trend of increasing resistivity with decreasing pore pressure. At about 1.5 bars there is a change in slope. Further investigation is needed, but this change in slope is probably caused by the first boiling to occur in the largest, most accessible pores. One idea is that boiling may occur over a range of temperature because of the higher surface tension, or suction potential, that exists in pores of smaller radii. This probably accounts for the slope of the segment at lower pressure. This result is in basic agreement with the experiment performed without explicit pore pressure control (Figure 1); decreasing the pressure (confining pressure in Figure 1, pore pressure in Figure 3) causes a large increase in resistivity at high temperature as steam is allowed to form in the pores.

\section{FUTURE PLANS}

Data will be collected in a system where pore pressure and confining pressure are servo-controlled to permit operation at constant pressure as the temperature is cycled. Currently, this is achieved by manual adjustment, which is laborious and time-consuming. In addition, such adjustment makes it difficult to study long-term changes in resistivity of the system.

\section{INDUSTRY INTEREST AND TECHNOLOGY TRANSFER}

Organization

Unocal Geothermal

EMI
Unocal Geothermal

New England Research
Type and Extent of Interest

Application of observations to geophysical studies
Elevation of boiling temperature by small pores

Experimental apparatus and method

\section{REFERENCES}

Persoff, P., and J. B. Hulen, Hydrologic Characterization of Four Cores from the Geysers Coring Project, Twenty-first Annual Stanford Geothermal Reservoir Engineering Workshop, 313-317, 1996.

Roberts, J. J., B. P. Bonner, and A. G. Duba, Electrical Properties of SB-15D Rocks at Reservoir Conditions, Symposium on Research Results from the Geysers Coring Project, Santa Rosa, CA, 1996a. 
Roberts, J. J., B. P. Bonner, A. G. Duba, and D.L. Schneberk, Physical Properties of Preserved Core from The Geysers Scientific Corehole, SB-15D, UCRL-JC123214, Twenty-first Annual Stanford Geothermal Reservoir Engineering Workshop, 313-317, 1996b.

\section{CONTACTS}

\section{DOE Program Manager:}

Marshall Reed

Office of Geothermal Technologies, EE-12

U.S. Department of Energy

1000 Independence Ave., SW

Washington, DC 20585

Phone: (202) 586-8076

Fax: (202) 586-8185

Email: Marshall.Reed@hq.doe.gov

Peggy Brookshier

Office of Program Management

U.S. Department of Energy

Idaho Operations Office

785 DOE Place, MS 1220

Idaho Falls, ID 83402

Phone: (208) 526-1403

Fax: (208) 526-6249

Email: BROOKSPA@INEL.GOV

\section{Principal Investigators:}

Al Duba, L201

Lawrence Livermore National Laboratory

P.O. Box 808

Livermore, CA 94551

Tel: (510) 422-7306

Fax: (510) 423-1057

Email: alduba@llnl.gov

Brian Bonner, L201

Lawrence Livermore National Laboratory

P.O. Box 808

Livermore, CA 94551

Tel: (510) 422-7080

Fax: (510) 423-1057

Email: bonner1@llnl.gov 
Jeff Roberts, L201

Lawrence Livermore National Laboratory

P.O. Box 808

Livermore, CA 94551

Tel: (510) 422-7108

Fax: (510) 423-1057

Email: roberts17@llnl.gov

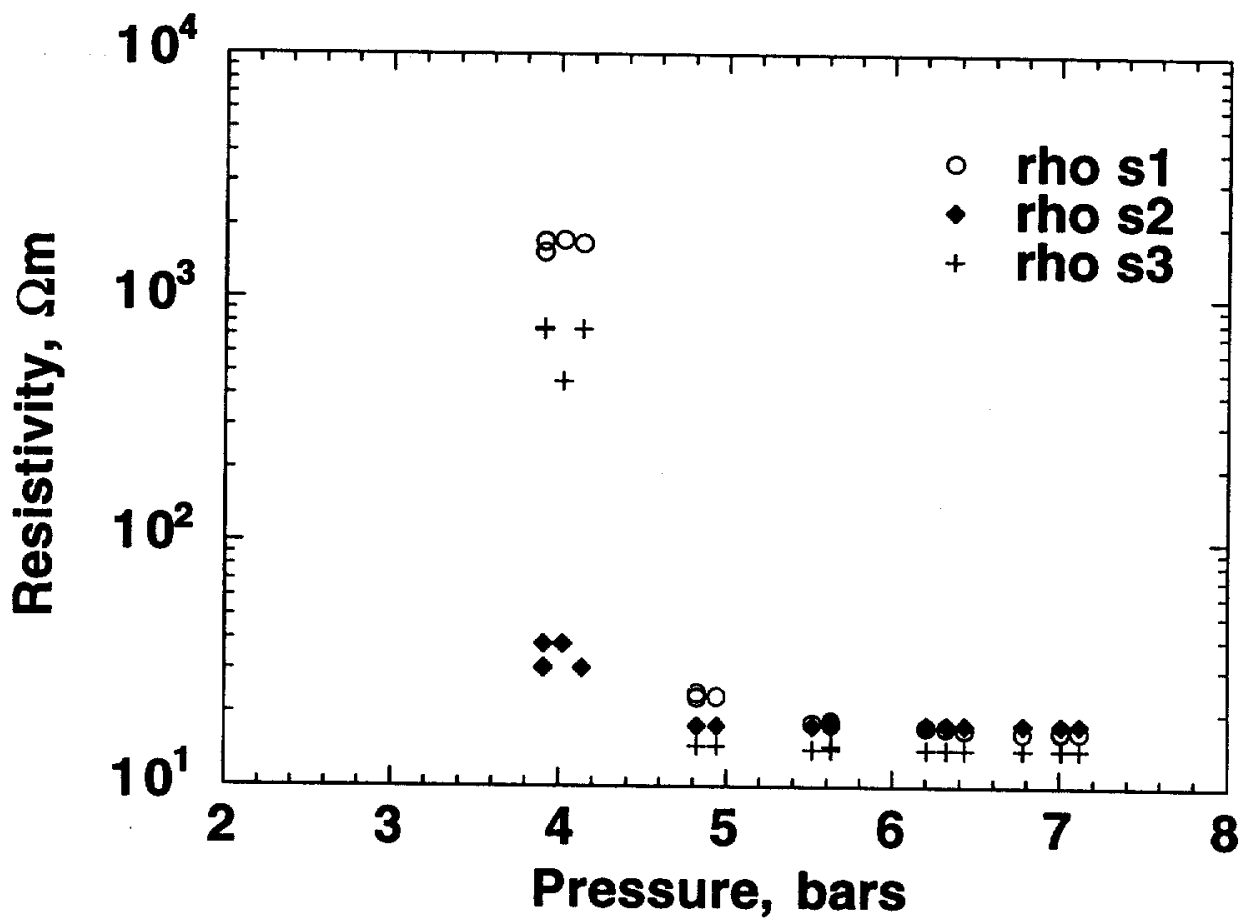

Figure 1. Resistivity of three SB-15D samples at $145^{\circ} \mathrm{C}$ as a function of confining pressure. 


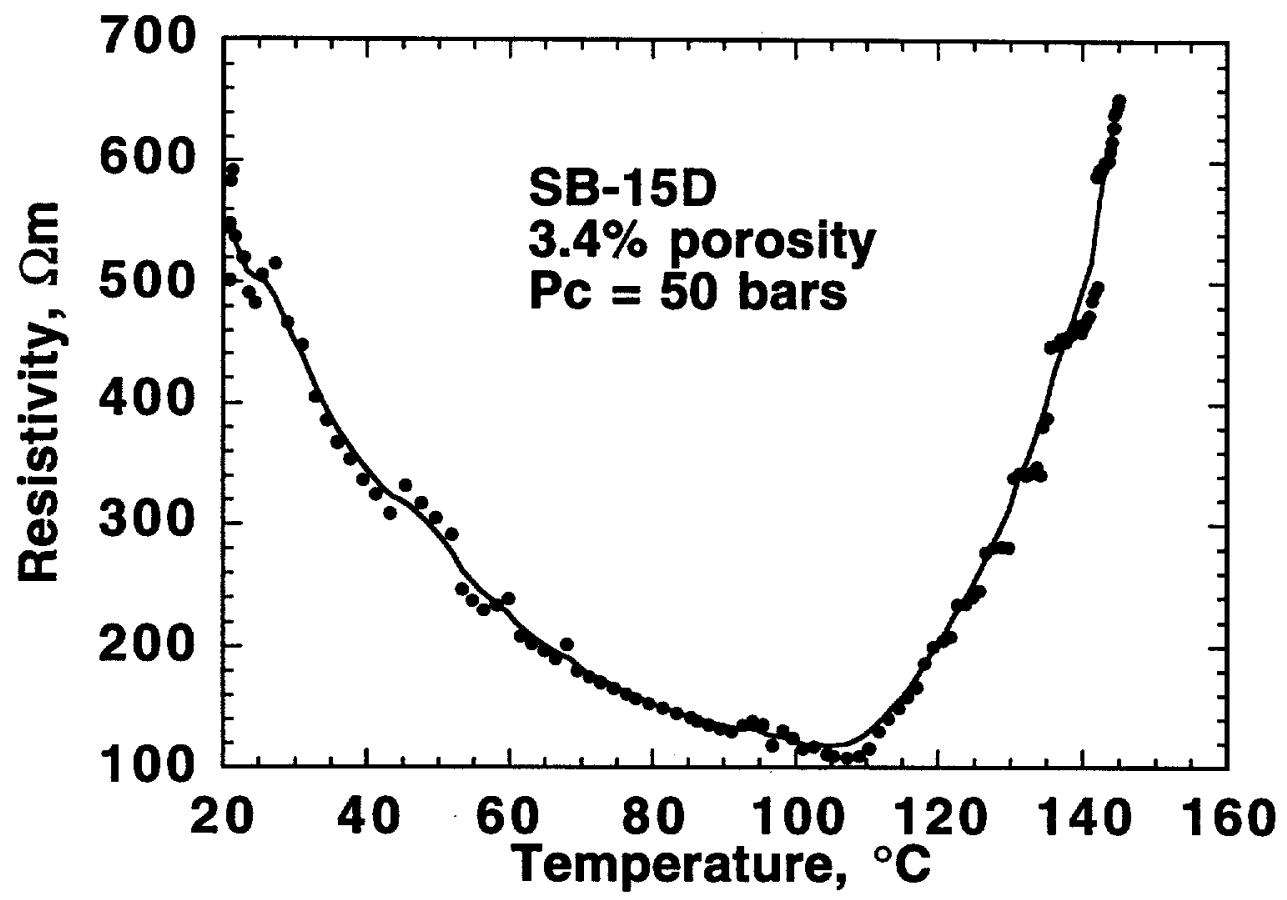

Figure 2. Resistivity of one SB-15D sample as a function of temperature at a confining pressure of 40 bars. Pore pressure was explicitly controlled to -15 and less than one bar on either end of the sample. This permitted boiling to occur on the low pressure end of the sample. 


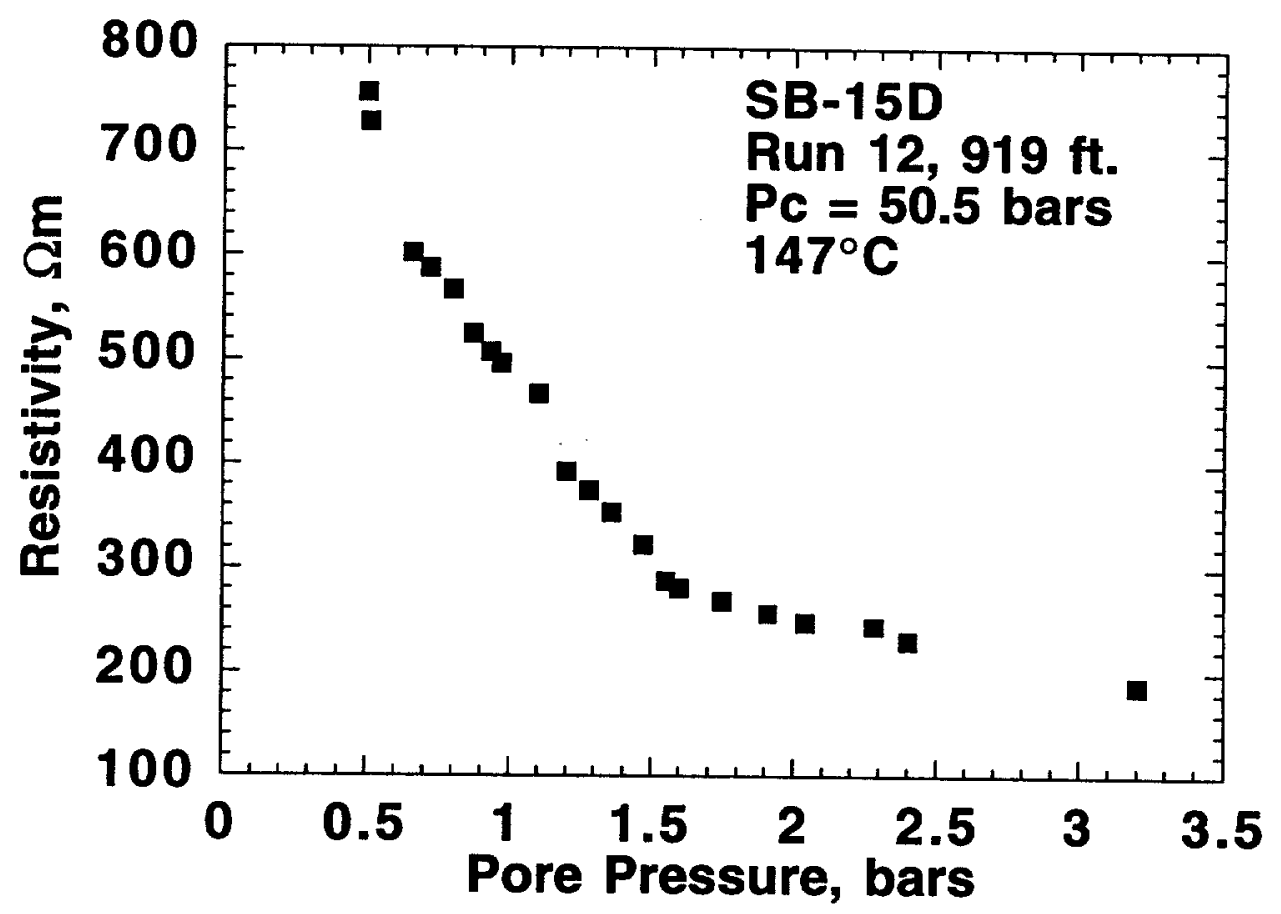

Figure 3. Resistivity as a function of pore pressure for a sample from SB-15D, Run 12, $919 \mathrm{ft}$. Confining pressure was held to $\sim 50.5$ bars and temperature was $147^{\circ} \mathrm{C}$. The pore pressure on one end of the sample was held to 15 bars while the low pressure end was varied. 


\title{
INTERPRETATION OF FTELD SEISMIC OBSERVATIONS AT THE GEYSERS GEOTHERMAL FIELD IN THE CONIEXT OF LABORATORY MEASUREMENTS
}

\author{
G. N. Boitnott \\ New England Research, Inc.
}

\section{KEY WORDS}

The Geysers, Velocities, Seismic, Laboratory Measurements, Tomography, NEGU-17, SB-15-D, The Geysers Coring Project, Saturation, Fractures

\section{PROJECT BACKGROUND AND STATUS}

A number of field seismic studies have been performed at The Geysers, including the work of $O^{\prime}$ Connell and Johnson [1991], Romero et al. [1995] and Julian et al. [1996]. Much of the work has been aimed at assessing the distribution of saturation within the reservoir, with interpretations based largely on assumptions that traditional poro-elastic theories apply. Here we present evidence that calls into question the validity of some of these assumptions at The Geysers. We make use of recent laboratory measurements on reservoir matrix material to provide a context within which to critically evaluate and interpret the field seismic data.

\section{PROJECT OBJECTIVES}

Unexpected decline in steam production at The Geyscrs geothermal field has highlighted the need for better technology to characterize and monitor water content within geothermal reservoirs. Using a simple field scaling model, Boimott [1995] showed that saturation effects on the seismic velocities of typical reservoir material could potentially cause seismic anomalies observed by $O^{\prime}$ Connell and Johnson [1991], thus supporting the notion that field seismic measurements could be useful for reservoir characterization and monitoring. However, the model, in conjunction with laboratory data, suggests that the underiying physics causing the amomaly is not the typically assumed bulk modulus reduction with de-saturation as predicted by poro-elastic theory, but rather is rooted in a shear velocity increase due to chemo-mechanical hardening of the matrix in response to drying. Here we extend this model to the three dimensional data-set from Romero et al. [1995], and critically cvaluate interpretations of observed anomalies from other studies as well.

\section{TECHNICAL OBJECTIVES}

- Formulate a model for interpretation of field seismic data which makes use of laboratory data and includes the effects of compliant field scale features such as joints and faults.

- Examine field scale inversions of velocity heterogeneity within The Geysers reservoir and critically evaluate interpretations based on traditional rock properties models.

EXPECTED OUTCOMES

- Improved interpretation of field seismic observations in geothermal reservoirs.

- Improved design of furure field seismic experiments for reservoir characterization and monitoring. 
- Assessment and development of a methodology to infer fracture properties (such as density and compliance) and water saturation from field seismic data.

\section{APPROACH}

Recently collected laboratory data on matrix material from The Geysers (boreboles NEGU-17 and SB-15-D) are used to constrain interpretations of field seismic velocities within The Geysers reservoir. Previous interpretations are critically evaluated in the context of the laboratory data through the use of a field-scaling model. Three working hypotheses are considered to explain the observations.

\section{RESTARCH RESULTS}

Low $\left(V_{P} / V_{S}\right)$ ratios within The Geysers have been interproted as reflecting undersaruration, with these interpretations being based on predictions from poro-elastic theory. These interpretations are based on the argument that the presence of an incompressible fluid (i.e. liquid water as opposed to steam) increases the effective bulk modulus of the reservoir, thus increasing the compressional velocity. It follows that in a low porosity reservoir such as The Geysers, if the anomalies are controlled by variations in saturation, one should expect to see a positive comviation between $V_{P}$ and $V_{P} / V_{S}$ and no correlation between $V_{S}$ and $V_{P} / V_{S}$.

Examination of three dimensional inversions of compressional and shear velocities do not seem to support such a conclusion. The lack of a correlation between $V_{P}$ anomalies and $V_{P} / V_{S}$ was noted by Julian et al [1996] and interpreted to reflect the fact that lithologic variations were masking the $V_{P}$ anomaly. They also appealed to variations in effective stress (due in part to depletion) as contributing to the anomaly in places; however in tho context of their model, one should expect systematics between $V_{P}$ and $V_{P} / V_{S}$ if pressure variations contribute to the anomalies.

The iuversion results of Romero et al [1995] for the Nothwest Geysers are presented in Figure 1. There are a number of interesting pafterns to point out. First. there is little correlation between $V_{P}$ and $V_{P} / V_{S}$. Second, a clcar negative correlation exists between $V_{S}$ and $V_{P} / V_{S}$. Third, the variation in $V_{P} / V_{S}$ decreases with depth. but there is no systematic change in the average value of $V_{P} / V_{S}$ with dopth.

The apparent $V_{S}$ domination of the $V_{P} / V_{S}$ signature is intriguing in light of observations in laboratory studies of shear weakening with saruration. In Figure 2. laboratory values of $V_{P} / V_{S}$ for dry and saturated samples are plotted against $V_{P}$ and $V_{S}$. Note how changes in $V_{S}$ with saturation appear to dominate the changes in $V_{P} / V_{S}$ for many samples. This $V_{S}$ domination of the $V_{P} / V_{S}$ variation is understood to reflect a chemo-mechanical weakening of the shear modulus dos to the presence of water. and has been found to comelate with illite content within the samples (seo Boitnott [this issue]). A modified Biot poro-elastic theory [see Boimott and Boyd 1996] predicts the observed effects, including the lack of correlation between $V_{P} / V_{S}$ and $V_{P}$. This lack of correlation occurs because the shear modolus reduction acts to reduce $V_{P}$, counteracting the increase in $V_{P}$ due to "Biot stiffening".

Although the similar patterns observed in the laboratory and the ficld might lead one to conclude that saturation effects are cansing the observed variations in $V_{P} / V_{S}$, the inference is clouded by the fact that field values of velocities are considerably 
lower (particularty at shallow depths) than velocities observed in the laboratory. This "scaling problem" is well understood to refiect the effects of field scale compliant features (joints and faults) which act to reduce the velocities, yet it makes it difficult to assess whether variations in matrix properties are visible in the field data.

A field-scaling model has been implemented to provide a means to separate matrix signal from the effects of field-scale features. The model inchudes two parts, a matrix model and 2 scaling model. The matrix model consists of a set of parameters sufficient to specify $V_{P}$ and $V_{S}$ of the matrix under both saturated and dry conditions. The matrix model can simply be a direct use of empirical data or it can be a physical model such as the modified Biot model discussed in Boimott and Boyd [1996]. The matrix can be assumed to be either homogeneous or heterogeneous at the scale of the ficld observations. The scaling model follows that of Boitnote [1995] in order to inchude the effects of fleld scale compliant features. The scaling model involves a set of parameters sufficient to specify the two independent variables $\left(K_{f}\right.$ and $\left.G_{f}\right)$ which encompass the added compliances resulting from field scale features.

Modeling results are discussed in more detail by Boitrott and Kintpatrick [1997]. An example of a modil simnlation is shown in Figure 3. Note the similar character between the data (Figure 1) and the model (Figure 3). The model in Figure 3, which is to thought to be the simplest model which mimics the data, requires spatial rariation in the ratio $K_{f} / G_{f}$ and assumes a homogeneons matrix. The rectuction in variation in $V_{P} / V_{S}$ with increasing depth is explained by the effect of pressure on the stiffnesses of joints and faults, and does not require any systematic variation in $K_{f} / G_{f}$ or fracrure density with depth. Thus the fracture properties can be assumed to be statistically uniform throughout the reservoir.

The magnitude of the correlation between $V_{S}$ and $V_{P} / V_{S}$ cannot be explained by the variations in saturation of the matrix alone. Thus the correlation must reflect, at least in part, processes acting on the field scale features. Adding spatial variations in saruration of the matrix acts only to lessen the amount of variation in $K_{f} / G_{f}$ required to match the data. In order to produce the negative correlation between $V_{S}$ and $V_{P} / V_{S}$ while maintaining no correlation between $V_{p}$ and $V_{P} / V_{S}$, a negative correlation between variations in $K_{f}$ and $G_{f}$ must be enforced. This correlation is physically consistent with the notion that increases in $V_{P}$ due to increases in $K_{f}$ with saturation (i.e. traditional poro-elastic mechanisms) are mitigated by decreases resulting from a reducton in $G_{f}$ with saturation. This rectuction is analogous to the observed reduction in the shear modulus of the matrix with saturation observed in the laboratory. Such an interpretation offers an explanation for why observed $V_{P} / V_{S}$ anomalies do not correlate with $V_{p}$ anomalies, pointing out that, at least at The Geysers, $V_{P}$ measurements alone may not be helpful in mapping water content within the reservoir.

The model provides a means with which to separate matrix properties from properties controlled by field scale features. It suggests that observed variations in $V_{P}$ are dominated by variations in fracture compliance and/or density. Having constrained these fracture properties from the $V_{P}$ observations, one can then make use of $V_{S}$ data. in conjunction with the $V_{P}$ interpretation, to infer saturation (or whatever is causing the $V_{S}$ correlation with $\left.V_{P} / V_{S}\right)$. The model may be even more powerful in aiding interpretalions of changes in field scaie velocities with time, where it can be used to 
help distinguish between phenomena influencing matrix properties from those influencing field scale features such as joints.

Other interpretations are also plausible. First, it is possible that errors in $V_{S}$ estimates are swamping any potencial signal, and that the $V_{S}$ and $V_{P} / V_{S}$ anomalies are largely the result of random error. This issue is being studied in collaboration with Ann Kirkpatrick at LBNL. Second, anisotropy in fracture orientations may be another physical mechanism through which to produce the negative comelation between variations in $K_{f}$ and $G_{f}$. This is being explored through an extension of the field scaling model to include anisotropy and will also be aided by planned shear-wave splitting studies at The Geysers by Jose Rial at UNC.

\section{FUTURE PLANS}

Laboratory experiments are underway to constrain the emount of shear weakening at low frequencics (quasi-static) as compared to that inferred from ultrasonic velocities. Other field data-sets are being explored to validate the observations, test to assure that the apparent $V_{S}$ domination of $V_{P} / V_{S}$ is not an artifact of the inversion process, and to extend the field scaling model to include tho effects of anisotropic. joint and fault distributions.

\section{INDUSTRY INTEREST AND TECHNOLOGY TRANSEER}

\begin{tabular}{c|c} 
Organization & Type and Extent of Interest \\
\hline $\begin{array}{c}\text { UNOCAL } \\
\text { Calpine Corp. } \\
\text { NCPA }\end{array}$ & Reservoir characterization and monitoring \\
\hline $\begin{array}{c}\text { LBNL } \\
\text { LNLL } \\
\text { USGS }\end{array}$ & Field seismic interpretation \\
\hline
\end{tabular}

\section{REFERENCES}

Boimoth, G. N., Laboratory measurements on reservoir rocks from The Geysers Geathcrmal Field, in Proc. 20th Workshop on Geothermal Reservoir Engineering, SGP-TR-150. 1995.

Boitnott, G. N., and P. J. Boyd, Laboratory measurements on reservoir rocks from the Geysers Geothermal Field, in Proc. 21st Wotkshop on Geothermal Reservoir Engincering, SGP-TR-151. 1996.

Boimott, O. N.. and A. Kirkpatrick, Interpretation of field seismic inversions at The Gcysers, in Proc. 22nd Workshop on Gcothermal Reservoir Engineering, SGPTR-152. in press 1997.

Julian, B. R., A. Ross, G. R. Foulger, and J. R. Evans, Three-dimensional seismic image of a geothermal reservoir. The Geysers, Califomia, GRL, 23,685-688. 1996.

O'Connell, D. R. H., and L. R. Johnson, Progressive inversion from hypocenters and P vave and $S$ wave velocity structure: application to The Geysers, California, 
geothermal field, JGR, 96, 6223-6236, 1991.

Romero, A. E., T. V. McEvilly, E. L. Majer, and D. Vasco, Characterization of the geothermal system beneath the Northwest Geysers steam field, Califomia, from seismicity and velocity patterns, Geothermics, 24, 471-487, 1995.

\section{CONTACTS}

Principal Irvestigator

Greg Boitmott

New England Research Inc.

76 Olcott Drive

White River Junction, VT, 05001

ph: $802-296-2401$

fax: 802-296-8333

int boitnott@ ner.com
Project Manager

Brian Bonner

LLNL

L-201

Livermore, CA 94550

ph: $510-422-7080$

fax: 510-423-1057

int: bonner 1 ilnlgov
Progran Manager

Marshall Reed

Geothermal Division

U.S. Dept. of Energy

Washington, DC 20585

ph: 202-586-8076

fax: 202-586-5124

int: MARSHALL.REED @hq.doe.gov 

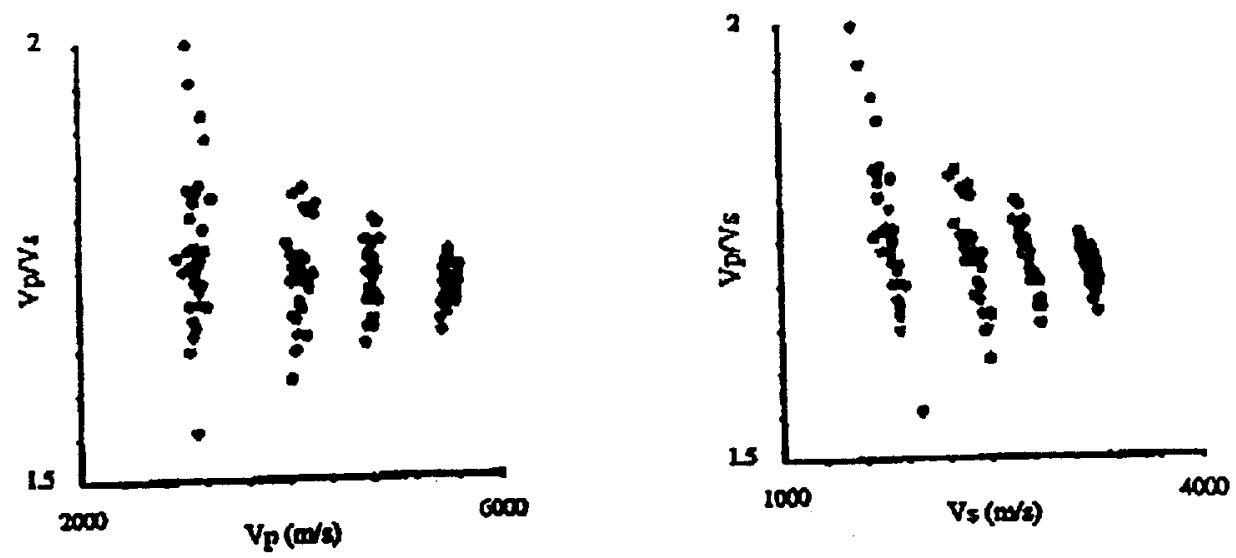

Figure 1: $V_{p}$ and $V_{S}$ versus $V_{p} / V_{S}$ from a three dimensional velocity inversion at the Northwest Geysers [data from Romero et al. 1995].
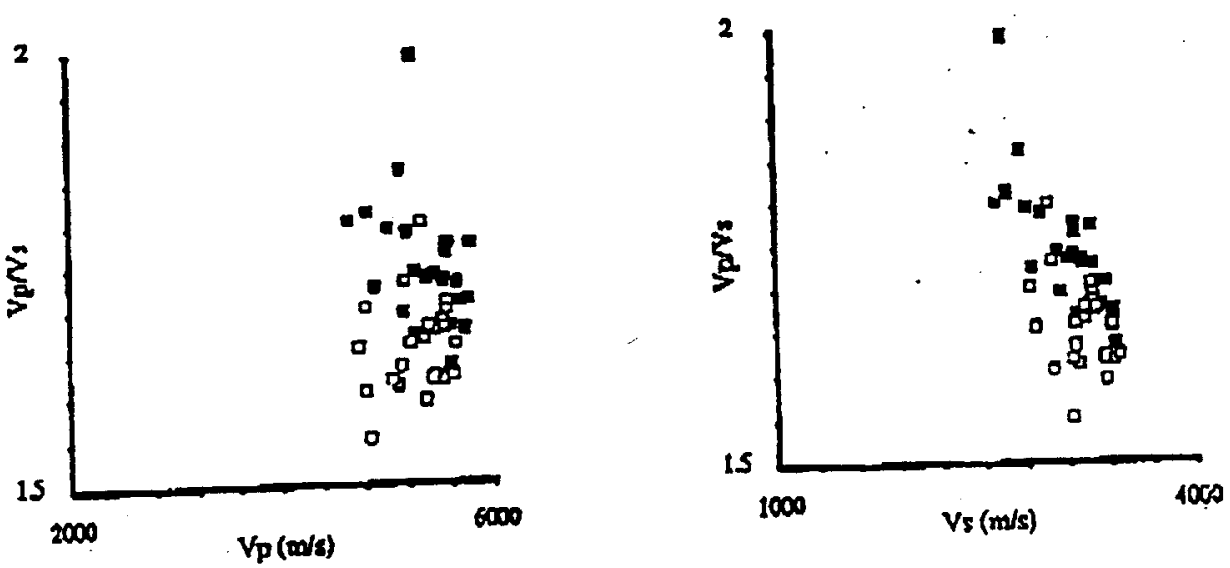

Figure 2: $V_{P}$ and $V_{S}$ versus $V_{F} / V_{S}$ from laboratory measurements on matrix material from The Geysers. Open symbols indicate dry matrix and filled symbols indicare saturated matrix.
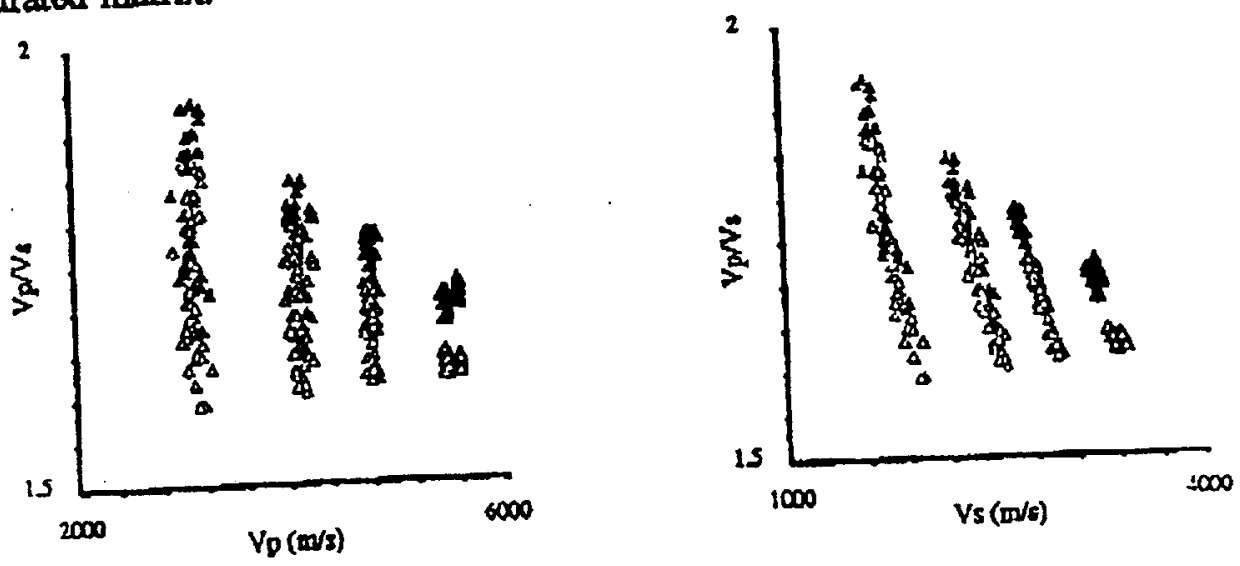

Figure 3. Stocinastic model simulation of the Northwest Geysers using a homogeneous model with variable saturation. Open symbols indicate dry matrix and matrix model indicate saturated matrix. 
Boitnott, G. N. (1995). "Laboratory measurements on reservoir rocks from The Geysers Geothermal Field, in Proc. 20th Workshop on Geothermal Reservoir Engineering, SGP-TR-150." :

Boitnott, G. N. and P. J. Boyd (1996). "Laboratory measurements on reservoir rocks from The Geysers Geothermal Field, in Proc. 21st Workshop on Geothermal Reservoir Engineering Stanford University." :

Bonner, B. P., J. J. Roberts, et al. (1994). "Determining water content and distribution in reservoir graywacke from the northeast Geysers with $\mathrm{x}$-ray computed tomography, Trans. Geothermal Resources council, 18, 305-310." :

Bonner, B. P., J. J. Roberts, et al. (1995). "X-ray tomography of preserved core from The Geysers scientific corehole, 20th Workshop on Geothermal Reservoir Engineering, Stanford University." :

Bruton, C. J., J. N. Moore, et al. (1997). "Geochemical analysis of fluid-mineral relations $i$ the Tiwi geothermal field, Philippines: Proc. Twenty-Second Workshop on Geothermal Reservoir Engineering Stanford Univ., Jan. 27-29, 1997, in press." :

Roberts, J. J., B. P. Bonner, et al. (1996). "Electrical Properties of SB-15D Rocks at Reservoir Conditions, Symposium on Research Results from the Geysers Coring Project, Santa Rosa, Ca." :

Roberts, J. J., B. P. Bonner, et al. (1996). "Physical Properties of Preserved Core from The Geysers Scientific Corehole, SB-15D, UCRL-JC-123214, Twenty-first Annual Stanford Geothermal Reservoir Engineering Workshop, 313-317." :

Roberts, J. J., B. P. Bonner, et al. (1996). "Physical properties of preserved core from the geysers scientific corehold, SB-15D." : 
Berge, P. A., Bonner, B.P. and Berryman, J.G. (1995). "Ultrasonic velocity-porosity relationships for sandstone analogs made from fused glass beads, Geophysics 60, 108-119." :

Berryman, J. G. and P. A. Berge (1996). "Critique of two explicit schemes for estimating elastic properties of multiphase composites: Mechanics of Materials, 22, 149-164." :

Blair, S. C., P. A. Berge, et al. (1996). “Using two-point correlation functions to characterize microgeometry and estimate permeabilities of synthetic and natural sandstones: J. Geophys. Res., in press." :

Blair, S. C. (1997). "A new reflective optical extensometer (ROX) system for geomechanical deformation measurements, submitted to NYRocks'97 International Symposium of the Int. Soc. Rock Mech., New York, June 29-May 2, 1997." :

Bonner, B. P., J. J. Roberts, et al. (1995). "X-ray tomography of preserved core from The Geysers scientific corehole, 20th Workshop on Geothermal Reservoir Engineering, Stanford University." :

Brenan, J. M., H. F. Shaw, et al. (1996). "Experimental Determination of Trace-Element Partitioning Between Pargasite and a Synthetic Hydrous Andesitic Melt (Vol 135, Pg 1, 1995) Earth Panet. Sci. Lett. 140, 287-288." :

Bruton, C. J., W. E. Glassley, et al. (1994). "Field-based tests of geochemical modeling codes using New Zealand hydrothermal systems: Lawrence Livermore National Laboratory, UCRL-ID-118009, 9 p." :

Bruton, C. J., W. E. Glassley, et al. (1995). "Geothermal areas as analogues to chemical processes in the near-field and altered zone of the potential Yucca Mountain, Nevada repository: Lawrence Livermore National Laboratory, UCRL-ID-118009, 9p." :

Carroll, S. A., M. Alai, et al. (1996). "Experimental investigation of cement, Topopah Spring Tuff, and water interactions at 200 degrees C." :

Carroll, S. A., E. Mroczek, et al. (1996). "Amorphous silica precipitation (60 degrees to 120 degrees $\mathrm{C}$ ): Comparison of laboratory and field rates." : 
Heikkinen, D. W. and L. J. Hainsworth (1996). "Pixe analysis of Mammoth Mountain Pine Trees - Growth Rings and Needles, Fifth International Conference on Nuclear Microprobe Technology and Applications, Santa Fe." :

Lin, W. J., J. J. Roberts, et al. (1995). "The effect of rock-water interaction on permeability, Eighth International Congress on Rock Mechanics UCRL-JC-116419 LLNL." :

Mathez, E. A., A. G. Duba, et al. (1996). "Electrical conductivity and Carbon in metamorphic Rocks of the Yukon-Tanana Terrane, Alaska, in press, J. Geophys. Res.,." : 100, 10,187-10,196.

Minarik, W. G. and E. B. Watson (1995). "Interconnectivity of Carbonate Melt at Low Melt Fraction. Earth and Planetary Science Letters." : 133, 423-437.

Nimz, G. J. and G. B. Hudson (1996). "Lithogenic, Cosmogenic and Noble Gas Nuclides in Catchment Hydrologic Systems. In Review. Invited chapter in Elsevier textbook; Isotopic Tracers in Catchment Hydrology." :

Nimz, G. J., M. W. Caffee, et al. (1996). "Affect of alkali fedlspar dissolution on the $\mathrm{Sr}$. isotopic composition of recently recharged groundwater, Wawona Basin, Yosemite National Park. In preparation for publication in Geology." :

Nimz, G. J., M. W. Caffee, et al. (1996). "Chlorine-36 evidence for upward movement of very old (Mesozoic?) connate groundwater along the Oakhurst lineament, Central Sierra Nevada Mountains, California. In preparation for submission to J. of Hydrology." :

Nitao, J. J. and T. A. Buscheck (1996). "Discrete-Fracture Modeling of Thermal-Hydrological Processes at G-Tunnel and Yucca Mountain American Nuclear Society,." :

Nover, G., S. Heikamp, et al. (1995). "The Effect of Pressure on the Electrical Conductivity of KTB Rocks, Surveys in Geophysics." : .16, 63-81.

Pena, C., S. C. Blair, et al. (1995). "Image analysis of tuff from the Yucca 
Mountain Project." : p. F197.

Pine, O., S. C. Blair, et al. (1995). "Mechanical Behavior of a $0.5 \mathrm{~m}$ block of Topopah Spring tuff under uniaxial compression." : P. F583.

Poirier, J. P. and A. G. Duba (1996). "On power-law kinetics of transprt phenomena in minerals, submitted to Physics and Chemistry of Minerals, July 1996." :

Roberts, J. J. and W. Lin (1995). "Permeability of fractured tuff as functions of temperature and confining pressure." :

Roberts, J. J. and W. Lin (1996). "Electrical properties of partially saturated Topopah Spring Tuff: Water distribution as a function of saturation." :

Roberts, J. M., B. P. Bonner, et al. (1996). "Physical properties of preserved core from The Geysers scientific corehole, SB-15D, 21st Workshop on Geothermal Reservoir Engineering Proceedings, Stanford University, 313-317." :

Roberts, J. J., B. P. Bonner, et al. (1996). "Electrical properties of SB-15D Rocks at Reservoir Conditions." :

Roberts, J. J. and W. Lin (1996). "X-ray radiography of fracture flow and matrix imbibition." :

Roberts, J. J. and W. Lin (1996). "Electrical properties of partially sturated Topopah Spring Tuff: Water distribution as a function of saturation." :

Roberts, J. J. and W. Lin (1996). "X-ray radiography of fracture flow and matrix imbibition,." :

Shankland, T. J., A.G. Duba, et al. (1996). "Increase of Electrical Conductivity with pressure as an indicator of conduction through a solid phase in Mid-crustal Rocks, submitted to J. Geophys. Res., 2/96." :

Tompson, A. F. and K. J. Jackson (1996). "Reactive transport in heterogeneous systems: An overview. In: Reactive Transport in Porous 
Media. (P.C. Lichtner, C.I. Steefel and E.H. Oelkers, eds.) Reviews in Mineralogy 34, Mineralogical Society of America." :

Wang, H. F. and J. G. Berryman (1996). "On constitutive equations and effective stress for deformable, double porosity media, Water Resources Res., to appear 1996." :

Wilt, M., K. Lee, et al. (1995). "Crosshole Electromagnetic Tomography- A new technology for Oil field characterization. The leading edge of exploration, published by the Society of Exploration Geophysicists." : p. 173-177. 